\title{
A revision of the spider genera Holcolaetis and Sonoita (Araneae: Salticidae)
}

\author{
F. R. Wanless
}

Department of Zoology, British Museum (Natural History), Cromwell Road, London SW7 5BD

\section{Introduction}

This present paper revises two closely related genera, Holcolaetis Simon, comprised of five species and Sonoita Peckham and Peckham, which is monotypic. Their geographical distribution is African, with the exception of one species of Holcolaetis which also occurs in North Yemen. Species of Holcolaetis are usually large, flattened and hairy, they are well camouflaged in life and superficially resemble species of Marpissa C. L. Koch, a large genus with several well known European species. They seem to be well adapted for living in confined spaces and much of their time is probably spent on tree trunks, however, they have also been found on cacti in association with the webs of other spiders. The only known species of Sonoita is on the other hand small and not flattened. The biology is unknown. Both groups, unlike many salticid genera, can be easily recognised not only by their general habitus, but by the presence of large posterior median eyes and also rather distinctive genitalia.

The taxonomy of Holcolaetis has been unusually muddled, primarily because Simon (1907) appears to have misidentified the type species subsequent to his original description. Further difficulties have arisen, in Holcolaetis especially, from a shortage of specimens making it difficult to match males and females, details of which are referred to in the descriptions. Compounding these problems is the fact that the epigynes of Holcolaetis females are unusually variable and also often plugged, both in the region of the copulatory openings and on the posterior margins.

The presence of large posterior median eyes in species of both genera, palpal median apophyses and abdominal pustuliform organs suggests that they belong in one of the more primitive branches of the Salticidae.

The standard abbreviations and measurements are those used by Wanless (1978), but for the leg spination the system adopted is that used by Platnick and Shadab (1975).

\section{Genus HOLCOLAETIS Simon}

Holcolaetis Simon, 1886: 394. Type species Holcolaetis xerampelina Simon, by monotypy. Simon, 1901: 452-454. Waterhouse, 1902: 414. Petrunkevitch, 1928: 181. Dyal, 1935: 218, 222. Neave, 1939: II: 671. Roewer, 1954: 937; 1965: 22. Bonnet, 1957: 2222. Prószyński, 1971: 417. Wanless, 1984: 136.

Holcolethis Simon 1909: 413. Neave, 1939: II: 671. [lapsus calami].

Definition. Flattened hairy spiders; medium to large in size i.e. total length between 4.0 and $16.0 \mathrm{~mm}$; sexes alike except males usually have longer more slender legs; colour patterns interspecifically similar - the abdomen characteristically marked with a broad dorsal dentate band; anterior leg spines strong on femora, otherwise absent or few and minute; males, females and subadults with pustuliform field more or less anterior to the first pair of abdominal apodemes.

Carapace: low, longer than broad, widest at about level of coxae II-III with transverse depression between posterior lateral eyes and fovea; fovea moderately long, positioned well behind posterior lateral eyes. Eyes: with moderately pronounced lenses set on low tubercles; laterals with black surrounds; anteriors closely set, equally or subequally spaced with apices procurved in frontal view; anterior laterals equal to or greater than half diameter of anterior medians; posterior medians relatively large, closer to and just outside optical axis of anterior laterals; posterior laterals more or less as large as anterior laterals and positioned well inside 

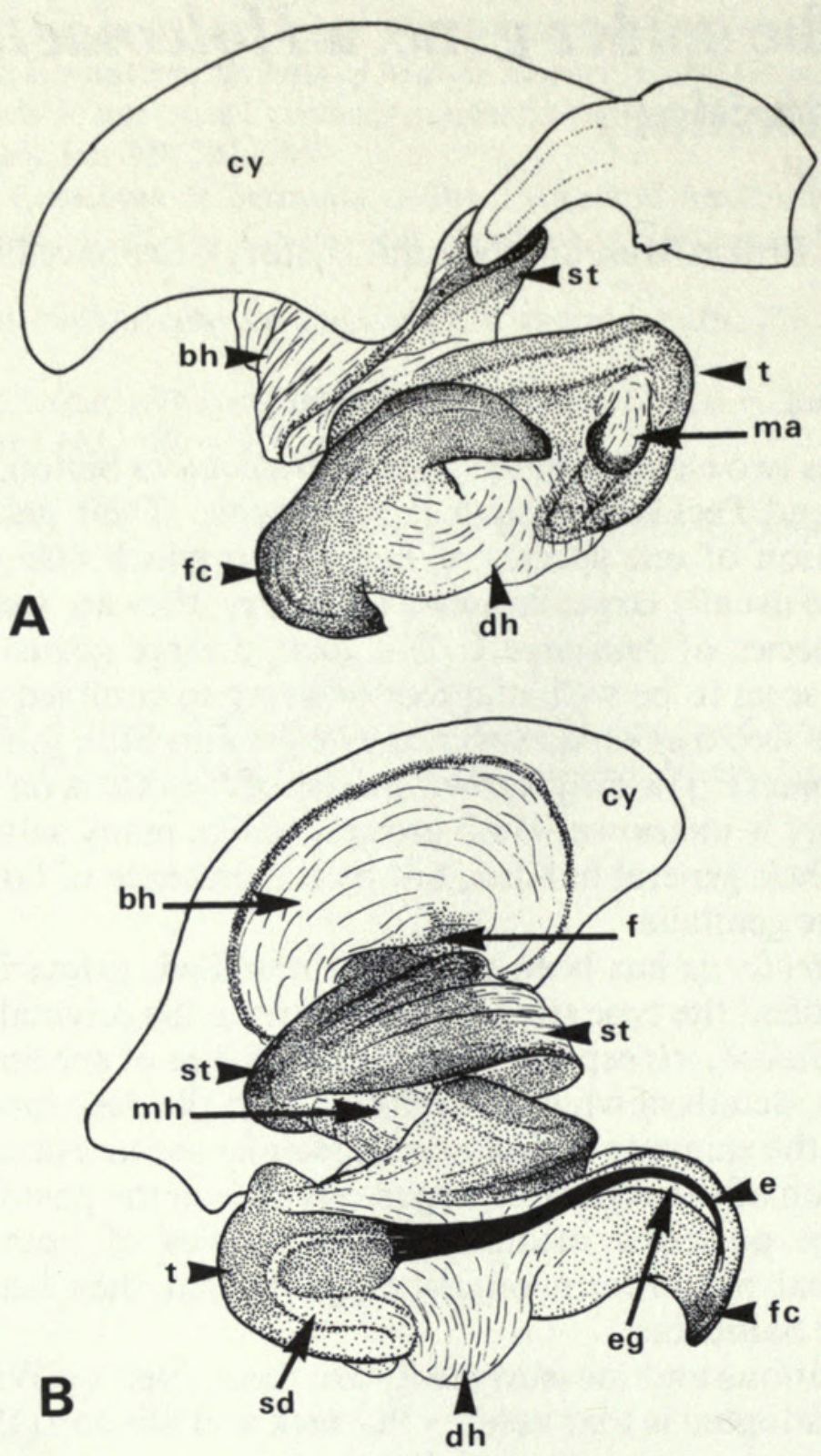

Fig. 1 Holcolaetis vellerea Simon, ô, expanded palp: A, retrolateral view; B, prolateral view. Abbreviations: bh, basal haematodocha; cy, cymbium; dh, distal haematodocha; e, embolus; eg, embolic guide; f, fulcrum; fc, functional conductor; ma, median apophysis; mh, median haematodocha; sd, seminal duct; st, subtegulum; t, tegulum.

lateral margins of carapace when viewed from above; posterior ocular quadrangle broader than long and slightly wider behind; entire quadrangle occupying between 35 and $43 \%$ of carapace length. Clypeus: low, between $10-26 \%$ of diameter of anterior median eyes. Chelicerae: robust, usually more bulbous in female; inclined anteriorly, more or less parallel; promargin with 4-6 teeth, retromargin with 6-10. Maxillae: long and diverging. Labium: longer than broad, about half maxillar length. Sternum: elongate scutiform, more attenuate in females. Pedicel: short. Abdomen: elongate ovoid with dorsal dentate band and indistinct pustuliform field; spinnerets moderately long, anteriors and posteriors more or less equal in length, but unequally robust, medians shorter and more slender, spigots of anterior spinnerets compact except for a single pair of longer spigots on inner margin, present in both sexes, but evidently more pronounced in females; former position of colulus indicated by group of setae between tracheal slit and base of anterior spinnerets; tracheal system apparently simple (only examined in $H$. vellerea Simon), the opening an obscure slit, not usually evident, just in front of the anterior spinnerets. Legs: moderately long and robust, strongest in females; anteriors often with strong fringes; claws smooth or pectinate; scopulae absent; tufts present; spines moderately strong, most numerous on 
posterior legs, on legs I usually lacking except on femora, basic pattern rather variable. Female palps: moderately long with an apical claw, distal segments sometimes darker than proximal ones.

Epigynes: Intergenerically and interspecifically fairly distinct, but intraspecifically sometimes variable and often plugged, both in area of copulatory openings and posterior margin. Generally characterised by delicate translucent posterior median flanges variable in development and occasionally damaged. Copulatory openings indistinct usually because of heavily sclerotised surrounds (Fig. 16); introductory ducts broad, moderately long, sometimes looped with separate or evidently fused glandular appendices (arrowed, Figs 4I; 16B,C) spermathecae rounded to avoid, relatively large and dark; fertilisation ducts leaf-like, obscured by dorsal membrane and apparently supported by apodemes.

Male palps: Intergenerically and interspecifically fairly distinct; complex and often rather dark; tibiae short to moderately long with robust prong-like retrolateral apophyses, some bearing pronounced flanges; cymbium with pronounced retrolateral lobe (arrowed, Fig. 3C), a small prolateral basal protuberance (arrowed, Fig. 3A) and distal scopula; embolus moderately long robust and curving sometimes partly hidden by embolic guide of functional conductor; distal haematodocha evident, in the unexpanded palp, as an oblong membraneous fold (arrowed, Fig. $3 \mathrm{~A})$ contiguous with the tegulum and functional conductor; tegulum broadly crescent-shaped (anterior portion obscured by functional conductor) containing a wide sinuous seminal duct and bearing occasionally a pronounced prolateral flange (arrowed, Fig. 8B-D); functional conductor large with an embolic guide and sometimes a massive prong; median apophysis bowl-like, but shallow and arising from membraneous region of the tegulum, in reality contiguous with the distal haematodocha; median haematodocha short and tube-like; subtegulum a ribbed ring-like sclerite, form of seminal reservoir indistinct; basal haematodocha large and bladder-like, i.e. in expanded palp.

REMARKs. There is no evidence as yet to support the hypothesis that pustuliform fields are pheromone dispersal sites. Furthermore, spheres found scattered over the organs and lodged in their pores (Wanless, 1984b) are probably contaminants (Humphreys, 1985) as they are consistent with the spheres covering the chorion of spiders eggs (Humphreys, 1983). The occurrence of $H$. vellerea in close proximity to alien egg-sacs (see below) and their egg guarding behaviour (Fig. 19) would undoubtedly expose them to such contamination.

The internal epigynal structures are usually very dark (Fig. 16) and deeply embedded in connective tissue which obscures detail even in lactic acid preparations. Although easily removed with fine entomological pins the process results in the destruction of the dorsal membrane, referred to above, which is consequently not shown in some of the vulvae illustrations, for example compare Figs 7D and 7E.

Hinge lines (Parry, 1957) are a common, but possibly overlooked feature of spider legs, they are in effect modifications of the cuticle indicating the site of muscle attachment. In Holcolaetis they are fairly conspicuous and usually evident, at low magnifications, as a pair of longitudinal bands on the dorsal surface of the tibiae, patellae and distal portion of the femora; on the last two segments they sometimes form patches rather than lines.

When examined by SEM, hinge lines are seen to be comprised of a series of triangular plates (Fig. 15) suggesting that they may provide for a degree of flexibility within the cuticle. The development and extent of hinge lines in other Salticidae is uncertain, casual observations with the optical microscope shows that they are not always evident and in general they are more conspicuous in dark robust legs than in pale slender ones. In other spider families, for example, the Thomisidae, they are sometimes well developed and clearly influence leg colour patterns, especially longitudinal markings. Similar cuticular structures have been noted in mites (Prof. G. O. Evans, pers. comm.) who also suggests that in areas where the cuticle is thin they may have a ventilatory function and allow for gaseous exchange at the site of muscle insertion.

DiaGnosis. Holcolaetis known only from Africa and N. Yemen may be distinguished from all other salticid genera by the large posterior median eyes and flattened body form. 
AfFINITIES. Holcolaetis is undoubtedly close to Sonoita, the relationship being supported by four possible synapomorphies, namely the characteristic form of the tegulum, median apophysis and distal haematodocha in males and epigynal flanges in females. Furthermore, pustuliform fields are present in both genera, but in Sonoita they are obscured by setae and comprised of fewer, more scattered pustuliform organs (Figs 13, 14).

Wanless $(1982,1984 a, 1984 b)$ suggested that on the basis of certain palpal characters (i.e. the presence of a movable median apophysis and pronounced functional conductor, (reduced in Allococalodes Wanless) that Holcolaetis and Sonoita were allied to Cocalodes Pocock and Allococalodes and furthermore they formed a group, the Cocalodes-group, which probably merited subfamilial rank. The hypothesis although seemingly tenable is open to question since it cannot be supported by other characters and furthermore, both the median apophysis and functional

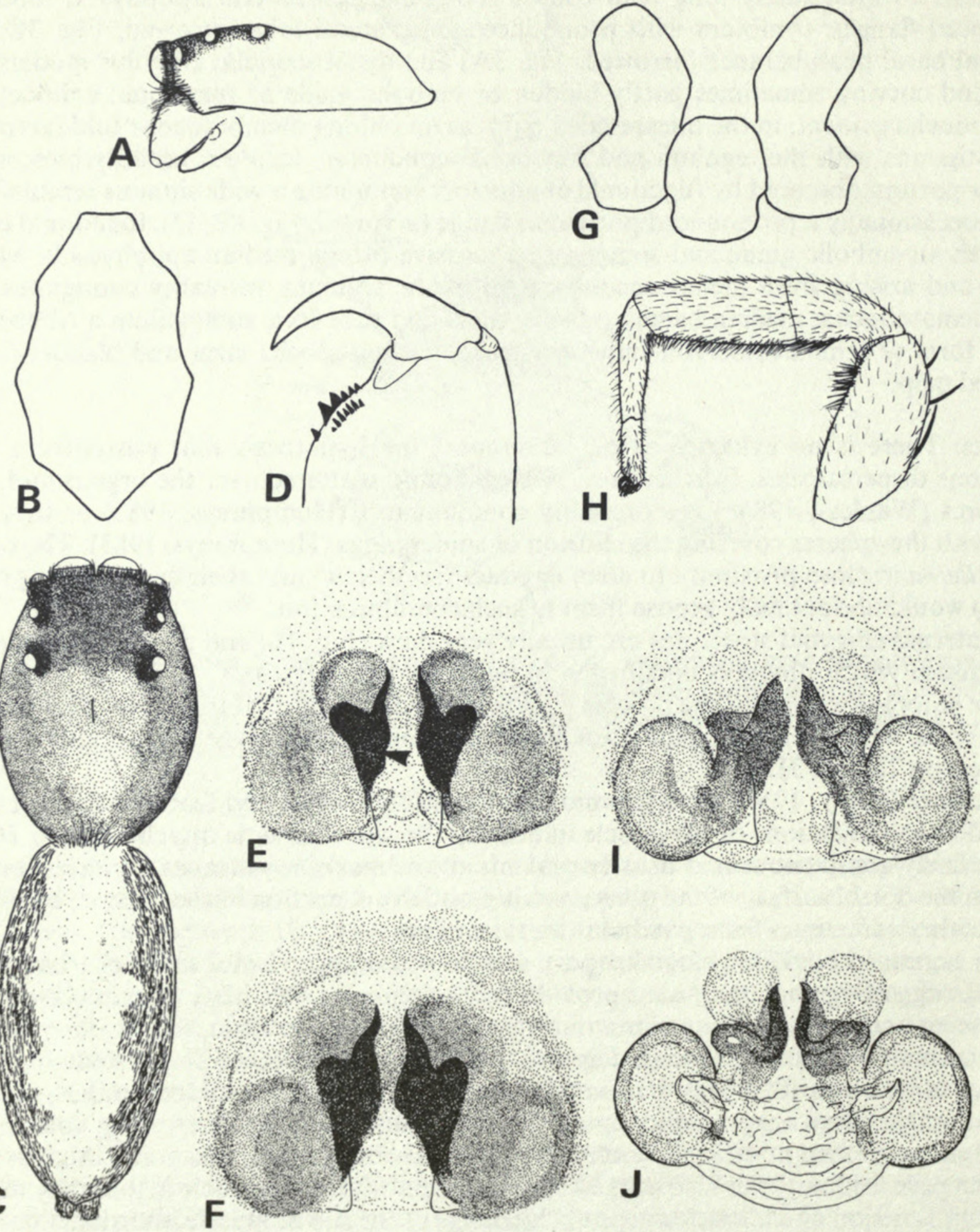

Fig. 2 Holcolaetis xerampelina Simon, lectotype from Zambia: A, carapace, lateral view; E, epigyne; G, maxillae and labium; H, leg I; I, vulva, outer view; J, vulva, inner view. 
conductor may have arisen several times within the Salticidae. An alternative grouping based on the assumption that the abdominal 'secretory' organs (see Wanless, 1984b) i.e. mytiliform and pustuliform fields, together with their specialized setae are homologous and synapomorphic for Spartaeinae and Holcolaetis/Sonoita is more acceptable. Unfortunately the incidence of abdominal 'secretory' fields in other spiders is largely unknown (see Wanless, 1984b) and since their presence can only be confirmed by SEM, they were initially overlooked in Sonoita, it is clear that earlier, possibly erroneous assumptions regarding their absence in Cocalodes and Allococalodes will have to be reviewed.

BIOLOGy. Little is known of the biology of Holcolaetis, collectors notes suggest that most species probably live on tree trunks. R. R. Jackson (pers. comm.) found Holcolaetis vellerea Simon, in Kenya, on the trunks of Euphorbia and cacti. There were no nests and some females were seen sitting on egg-sacs (Fig. 19A, B). The plants were wrapped up in webs, especially araneid webs and the Holcolaetis were sitting with araneid silk over them, usually very close. Sometimes they were under the edges of the silk of araneid egg-sacs, but they were never seen actually standing on alien silk.

\section{Check list and distribution of species in the genus Holcolaetis}

Holcolaetis $(*=$ type species $)$

H. albobarbata Simon

H. clarki sp. n.

H. vellerea Simon

*H. xerampelina Simon

H. zuluensis Lawrence

Angola; Cameroon; Uganda.

Angola; Cameroon; Ghana; Zaire.

Angola; Cameroon; Ivory Coast; Kenya; N. Yemen; Rwanda; São Thomé; Zaire.

Malawi; Tanzania; Zambia.

South Africa; Tanzania.

\section{Key to species of Holcolaetis}

Males

1 Functional conductor with massive apophysis (arrowed, Figs 3A; 5A; 6A); tegular flange absent

- Functional conductor without an apophysis; tegular flange present (arrowed, Figs $8 \mathrm{~B} ; 10 \mathrm{~A}$ ) (arrowed, Fig. 6A) (Kenya; South Africa; Tanzania)

zuluensis Lawrence (p. 259)

Tip of functional conductor hardly if at all sinuous; retrolateral tibial apophysis without well developed flange .

3 Embolus relatively robust and not obscured; distal haematodocha narrow (arrowed, Fig. 3A) (Malawi; Tanzania; Zambia) . . . . . . xerampelina Simon (p. 254)

Embolus relatively slender and partly obscured; distal haematodocha broad (arrowed, Fig. 5A) (East, Central and West Africa; N. Yemen) . _ . . . . . vellerea Simon (p. 255)

4 Retrolateral tibial apophysis with pronounced flange (arrowed, Fig. 10A, D) (Angola; Cameroon; Ghana;Zaire) . . . . . . . . . clarki sp. n. (p. 263)

Retrolateral tibial apophysis lacking pronounced flanges (Fig. 8A, B) (Angola; Cameroon; Uganda) . . . . . . . . albobarbata Simon (p. 262)

\section{Females}

1 Epigyne with conspicuous black copulatory openings more or less heart-shaped in profile (Fig. 2E) (Malawi; Tanzania; Zambia) . xerampelina Simon (p. 254)

- Epigyne otherwise

2 Copulatory openings arising within a dark more or less ovate depression (Fig. 7A; B) (Angola; Cameroon; Uganda)

- Epigyne otherwise

3 Copulatory openings arising within rounded depressions (Figs 6E-G; 9C,D)

- Copulatory openings arising within a broad ill-defined depression-more evident in specimens than in Fig. 4D-F (East, Central and West Africa; N. Yemen) . vellerea Simon (p. 255)

4 Introductory ducts hardly if at all evident through uncleared integument (Fig. 9C, D) (Angola; Cameroon; Ghana; Zaire)

clarki sp. n. (p. 263)

- Introductory ducts usually evident, especially black proximal regions (arrowed, Fig. 6G) Kenya; South Africa; Tanzania) 


\section{Holcolaetis xerampelina Simon}

(Figs 2, 3, 16A)

Holcolaetis xerampelina Simon, 1886: 394. LECTOTYPE 우 (here designated) Zanzibar, (MNHN, Paris). Simon, 1901: 453, 454; 1909 (1910): 413. Strand, 1909: 181. Petrunkevitch, 1928: 181. Roewer, 1954: 937. Bonnet, 1957: 2223. Prószyński, 1971: 417. Cutler, 1976: 132.

REMARKs. To judge from museum specimens and the literature there appears to have been some confusion over the identity of this species, primarily because Simon consistently identified $H$. zuluensis Lawrence as $H$. xerampelina Simon. Lessert (1925a) also misidentified $H$. xerampelina since the specimens he used for his illustrations are without doubt $H$. zuluensis. His identification was based on an earlier description by Strand 'Les pattes-machoires correspondent bien a la description de Strand (1909, p. 181)'. Strand's description is fairly detailed, but in the absence of figures and specimens the species cannot be identified with certainty.

Roewer (1965) merely perpetuated the problem by producing crude copies of Lessert's figures, a feature noted by Clark (1974). From correspondence and notebooks of the late Mr Clark $(\mathrm{BMNH})$ it is clear that he had correctly identified the majority of Holcolaetis species. Unfortunately, he misidentified the type specimen of $H$. xerampelina, selecting instead a specimen of $H$. zuluensis from Gabon that Simon had incorrectly identified as $H$. xerampelina. He therefore quite naturally assumed that $H$. zuluensis was a junior synonym. He did not, however, make a definite proposal (see Clark, 1974) and the synonymy was never accepted.

Diagnosis. Similar to $H$. vellerea and $H$. zuluensis, but separated by the narrow element of the distal haematodocha in males (arrowed, Fig. 3A), and the black somewhat heart-shaped profile of the introductory ducts in females (arrowed, Fig. 2E).

Female Lectotype, in fair condition. Carapace (Fig. 2C) dark reddish ringed black in eye region with broad pale orange band on thoracic part; clothed in grey/pale golden pubescent hairs with whitish ones on thoracic band; eye region rubbed, probably white haired; also, on margins and submargins indistinct narrow bands of short white hairs. Eyes: laterals with black surrounds; fringed by white hairs with dull pale amber ones around lower rims of anteriors. Clypeus: covered in pale greyish hairs. Chelicerae: dark red with scattered long amber hairs; promargin with six

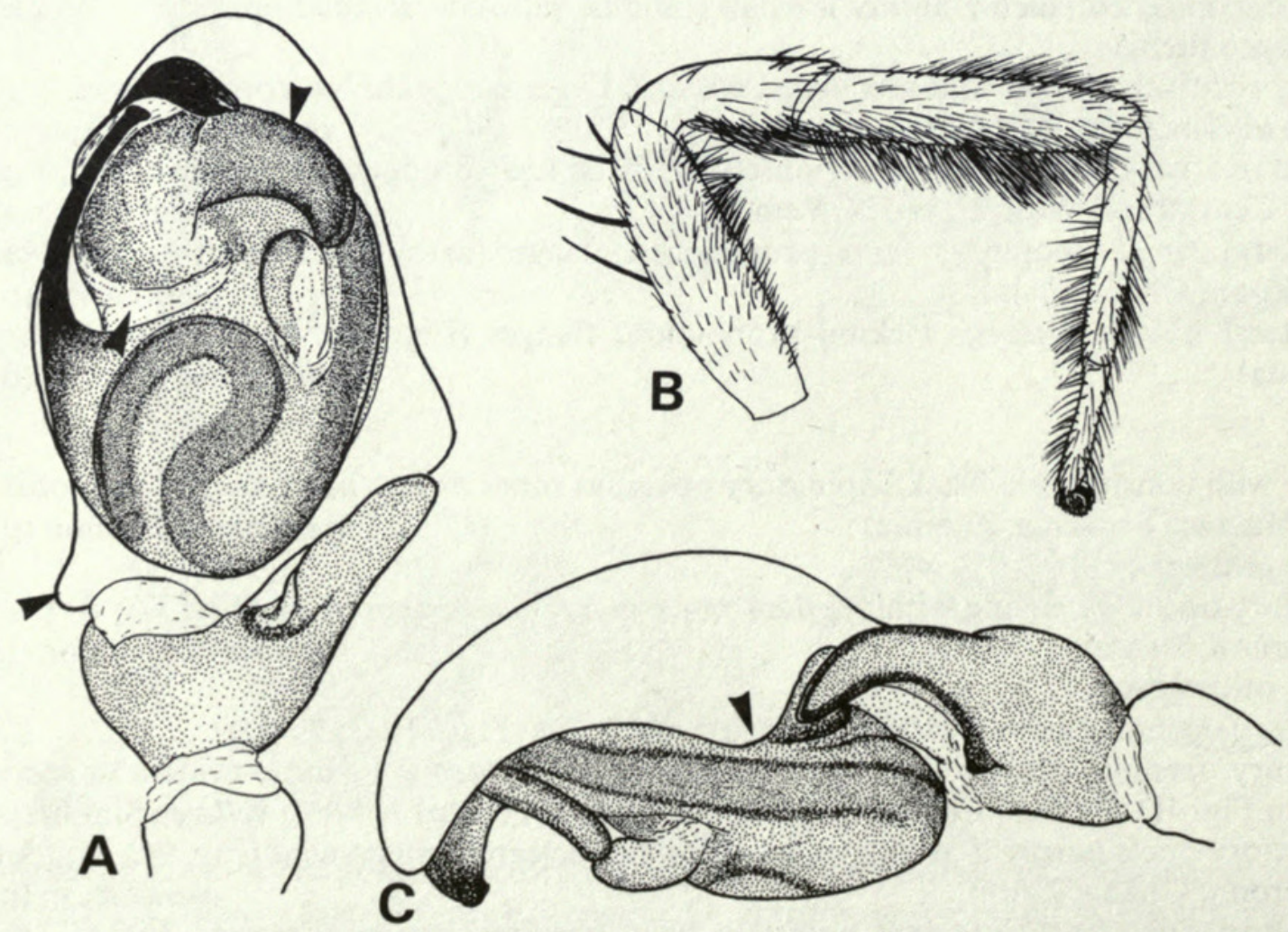

Fig. 3 Holcolaetis xerampelina Simon, ô, A, palp, ventral view; B, leg I; C, palp, retrolateral view. 
teeth, retromargin with seven. Maxillae: reddish with inner distal margins whitish yellow. Labium: dark reddish tipped whitish yellow. Sternum (Fig. 2B): yellowish orange with darker margins; shiny; thinly clothed in fine pale amber hairs with stronger whitish and amber hairs on margins. Abdomen: dorsum amber mottled black, clothed in amber hairs with broad central pale yellow dentate band clothed in pale creamy and scattered pale amber hairs; pustuliform field obscure; venter dirty pale yellow mottled black with three central black bands converging towards spinnerets; spinnerets amber tinged black. Legs: legs I (Fig. 2H): amber to dark amber lightly tinged black on tibiae; fringed with amber hairs on underside of tibiae, patellae and distal retrolateral side of femora; other legs generally amber with vague sooty annuli, dark on legs IV; also, on all legs scattered semirecumbent fringes of fine white hairs. Spines of legs I: femora $p$ 0-3-0, d 0-2-2. Palps: pale yellow becoming amber distally and on basal part of femora. Epigyne (Fig. 2F): clothed in fine hairs.

Dimensions $(\mathrm{mm})$ : total length $12 \cdot 5$; carapace length $5 \cdot 36$, breadth $4 \cdot 0$, height $1 \cdot 88$; abdomen length $7 \cdot 12$; eyes, anterior row $2 \cdot 76$, middle row $2 \cdot 78$, posterior row 2.92 ; quadrangle length 1.92 (35\% of carapace length). Ratios. AM : AL : PM : PL :: $18: 9 \cdot 5: 7 \cdot 1: 10 \cdot 5$; AL-PM-PL :: 13-17; AM : CL :: $18: 4$.

MALE from Malawi, in fair condition formerly undescribed. Carapace: dark orange brown tinged black especially on sides and in eye region; irregularly clothed in whitish and dull amber hairs (rubbed) with scattered brown-black ones on sides; also, on lower sides a narrow submarginal band of short white hairs. Eyes: laterals with black surrounds; fringed by pale amber hairs with conspicuous white ones on inner and outer parts of upper rims of anterior medians and on inner part of upper rims of anterior laterals. Clypeus: clothed in amber and long black hairs. Chelicerae: orange-brown lightly tinged black; thinly clothed in brown-black hairs; promargin with five teeth, retromargin with seven. Maxillae and labium: orange-brown lightly tinged black with inner distal margins of maxillae whitish. Sternum: orange-brown tinged black; shiny; clothed in scattered white and brown-black hairs. Coxae: yellow-brown, first pair lightly tinged black. Abdomen: with dorsal greyish white dentate band containing vague blackish markings and chevrons; sides blackish with scattered long amber hairs; venter grey tinged black, clothed in vague whitish hairs laterally and short amber ones medially - the latter forming a vague longitudinal band; spinnerets yellow-brown tinged black. Legs: first and to a lesser extent second pairs densely fringed in black hairs (Fig. 3B); generally yellow-brown tinged black except for light yellowbrown tarsi and metatarsi. Spination of legs I: femora p 0-2-1, d 0-3-2. Palp (Fig. 3A,C).

Dimensions $(\mathrm{mm})$ : total length $7 \cdot 92$; carapace length $3 \cdot 44$; breadth $2 \cdot 44$, height $1 \cdot 24$; abdomen length 4.6 ; eyes, anterior row 1.94 , middle row 1.88 , posterior row 1.92; quadrangle length 1.4 (40\% of carapace length). Ratios: AM : AL : PM : PL :: 15: 8.2:6: 7; AL-PM-PL :: 9-11; AM : CL :: $15:$ ca. $2 \cdot 5$.

VARIATION. Another female measures $11.0 \mathrm{~mm}$ total length, $4.88 \mathrm{~mm}$ carapace length.

Distribution. Malawi; Tanzania; Zambia.

Material eXAmined. Malawi: Chintheche, 10, I-II.1976, R. Jocque, MT. 147.920. (MRAC, Tervuren). Tanzania: Zanzibar, lectotype + , + juvenile, Raffray, (MNHN, Paris, 987). Zambia: Lake Mweru, Wantipa, from tree, 1ㅇ, ix.1944, P. D. L. Ghilbride, S.34, (BMNH. 1946.12.31.107).

\section{Holcolaetis vellerea Simon}

(Figs 1, 4, 5, 12, 15, 16B, 17-18)

Holcolethis vellerea Simon, 1909 (1910): 78. LECTOTYPE , (here designated) São Thomé, (MNHN, Paris) [examined]; [Holcolethis lapsus for Holcolaetis].

Holcolaetis vellerea: Roewer, 1954: 937; 1965: 26. Bonnet, 1957: 2222. Prószyński, 1971: 417. Clark, 1974: 16.

Holcolaetis vidua Lessert, 1927: 426. Holotype đే, Zaire, (AMNH, New York) [examined]. Dyal, 1935: 222 [?misidentification]. Roewer, 1954, 937: 1965: 27. Bonnet, 1957: 2223. Prószyński, 1917: 417. Clark, 1974: $16[=$ vellerea $]$. 

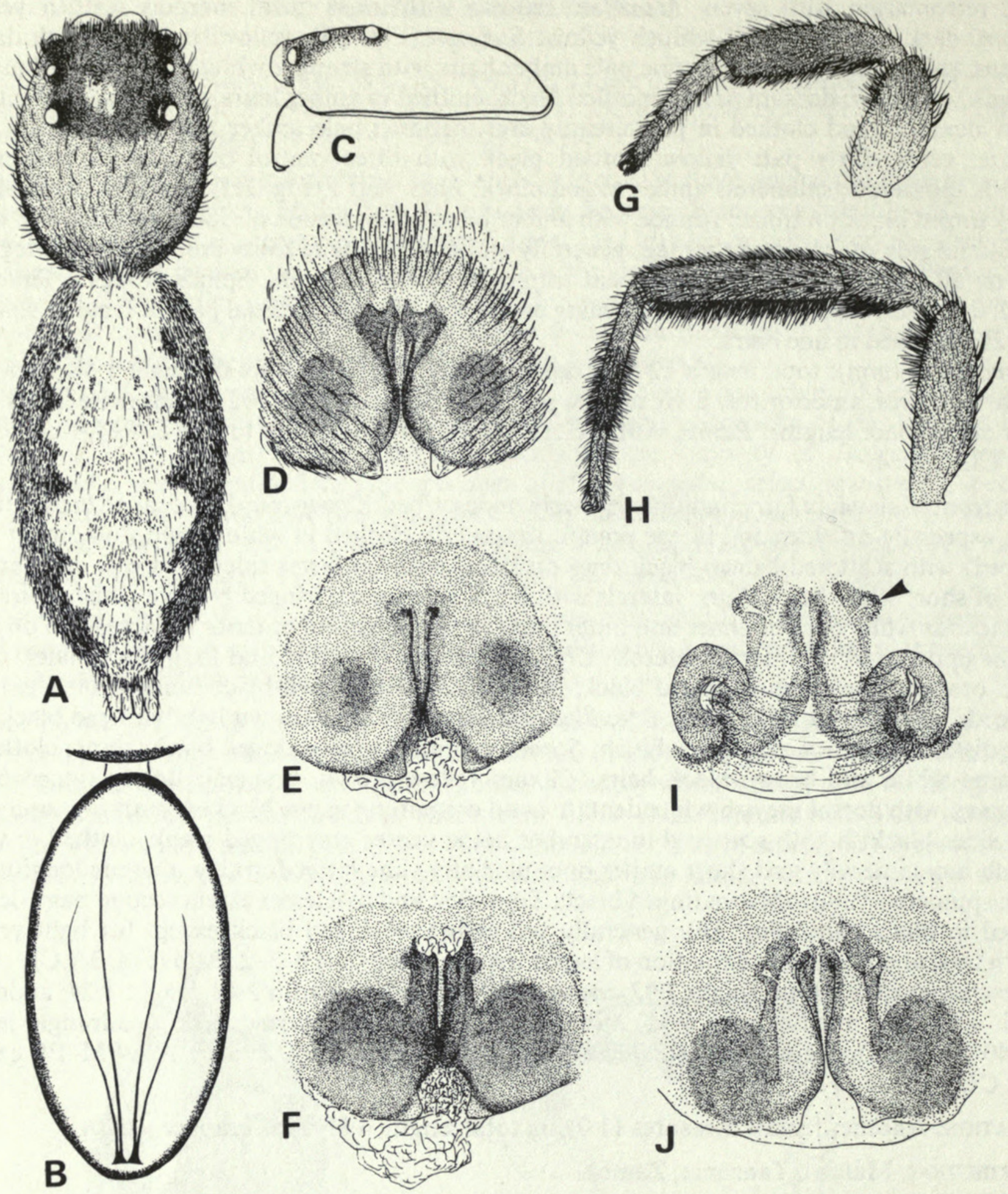

Fig. 4 Holcolaetis vellerea Simon, o from Rwanda: A, dorsal view; B, tracheal system - schematic; C, carapace, lateral view; D, epigyne; F, epigyne, another specimen; G. leg I; I, vulva, inner view; J. vulva, outer view. + from Kenya: E, epigyne. $\widehat{o}$ from Rwanda: H, leg I.

Holcolaetis camerunensis Roewer, 1965: 26. Holotype ${ }^{\star}$ Cameroon, (FS, Frankfurt am Main) [examined]. Prószyński, 1971: 417. Brignoli, 1983: 640. Syn. n.

Diagnosis. Similar to $H$. zuluensis, but separated by the relatively short tip of the functional conductor and absence of a pronounced flange on the retrolateral tibial apophysis in males (Fig. $5 \mathrm{~A})$. Females are distinguished, in spite of considerable epigynal variation and plugging, by the absence of rounded depressions surrounding the copulatory openings and also dark patches anterior to them. In reality the introductory ducts of $H$. zuluensis loop anteriorly and are visible through the integument as dark patches (arrowed, Fig. 6G). Whereas there are no such loops in $H$. vellerea and consequently no dark patches. 
MaLe from Rwanda, in good condition. Carapace: reddish orange with blackish eye region, marginal and submarginal bands; thickly clothed in whitish and pale amber hairs with scattered bristles and pattern of marginal bands comprised of white hairs bordered above by a band of black hairs and below by dark bare cuticle edged in white hairs. Eyes: laterals with black surrounds; fringed by dull amber and white hairs with scattered bristles behind anterior row. Clypeus: clothed in dull amber hairs with marginal fringe of long black ones. Chelicerae: dark reddish; thinly clothed in black hairs; promargin with five teeth, retromargin with eight. Maxillae and labium: dark reddish, the former with yellow inner distal margins. Sternum: dark brownish orange lightly tinged black; thinly covered in black hairs - fine in centre, coarse on margins. Coxae: first pair dark reddish, others orange-brown. Abdomen: with dorsal greyish yellow dentate band clothed in fine whitish hairs and scattered bristles; sides mottled black with fine brown-black hairs and bristles; venter similar to sides, but with four inconspicuous greyish stripes containing lines of amber spots; spinnerets dark brown tinged black; clothed in black hairs with whitish ones on posterior pair. Legs: legs I dark brownish orange lightly tinged black with inside of femora, basal half of metatarsi and tarsi paler, densely fringed in brown-black hairs with long whitish ones on inside of femora and patellae; also semirecumbent tufts of white hairs on inside face of basal half of metatarsi; legs II similar, but paler markings in greater contrast; legs III dark orange-brown faintly tinged black with yellow-brown metatarsi and tarsi-the former with blackish apices, clothed in long whitish and grey-black hairs with scattered semirecumbent tufts of white ones; legs IV similar to III except metatarsi darker. Spination of legs I: metatarsi v 2-0-0; tibiae v 1-0-0; femora d 0-3-3, p 0-0-1. Palp: as in Fig. 5A-B, but darker.

Dimensions $(\mathrm{mm})$ : total length $10 \cdot 2$; carapace length $4 \cdot 64$, breadth $3 \cdot 52$, height $1 \cdot 72$; abdomen length $5 \cdot 6$; eyes, anterior row $2 \cdot 38$, middle row $2 \cdot 32$, posterior row 2.36 ; quadrangle length $1 \cdot 8$ (38\% of carapace length). Ratios: AM : AL : PM : PL :: $18: 9: 6 \cdot 6: 9$; AL-PM-PL :: 6.6-9; AM : CL :: $18:$ ca. 4.

Female from Rwanda, in good condition. Similar to male. Carapace (Fig. 4A, C). Eyes: fringed by white hairs with some amber ones. Clypeus: clothed in long white hairs below median eyes

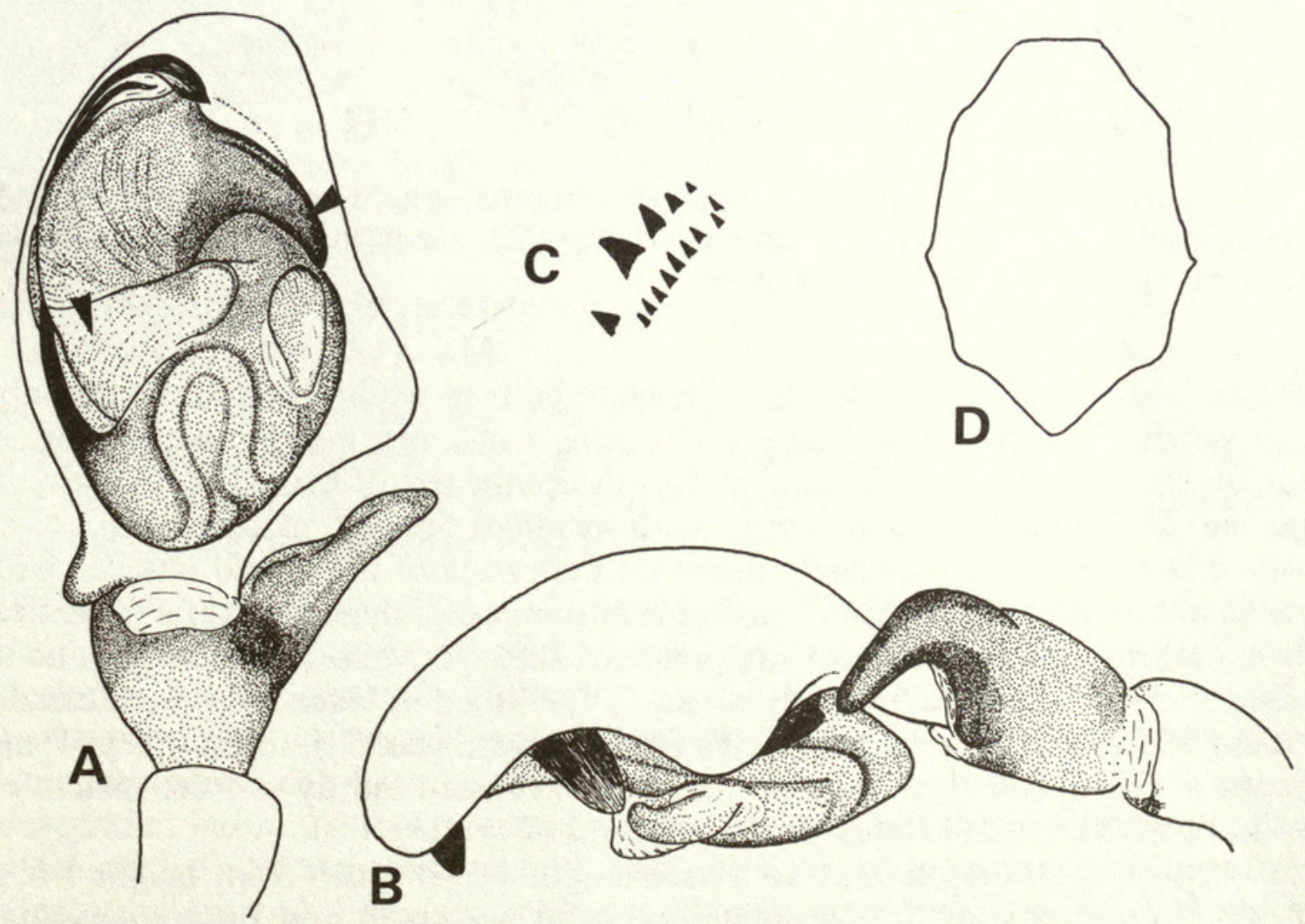

Fig. 5 Holcolaetis vellerea Simon, ơ from Uganda: A, palp, ventral view; B, palp, retrolateral view; C, cheliceral teeth; D, sternum. 

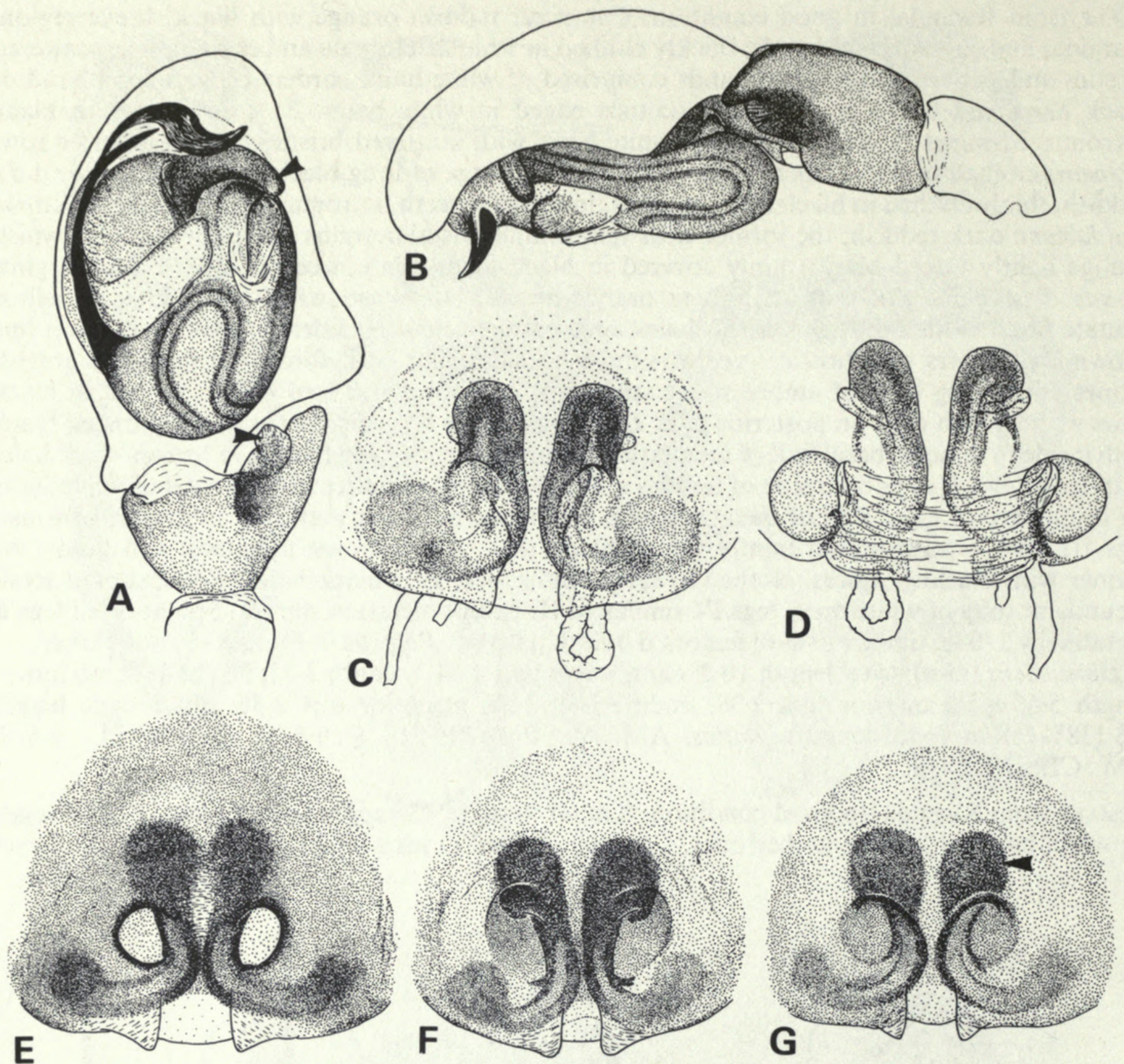

Fig. 6 Holcolaetis zuluensis Lawrence, ô from Pietermaritzburg. A, palp, ventral view; B, palp, retrolateral view. + from Parfuri: C, vulva, outer view; D, vulva, inner view. + type series: E-F, paralectotype, epigynes; G, lectotype, epigyne.

with amber and white ones below laterals - the white hairs in reality the start of the submarginal white haired bands. Chelicerae: promargin with four teeth, retromargin with eight. Abdomen: similar to male but with flecks and vague chevrons comprised of brown-black hairs in dentate band. Legs: legs I-II deep brownish orange with inside of femora, metatarsi and tarsi orangebrown; clothed in black hairs, especially dense on underside of tibiae and patellae with whitish hairs on inside of femora; also, on patellae, tibiae and inside of femora II tufts of semirecumbent white hairs; other legs light to dark brownish orange except for yellow-brown tarsi and metatarsi, the latter darker at either end particularly on legs IV; clothed in black hairs with usual scattered semirecumbent white tufts most numerous on femora and tibiae. Spination of legs I: metatarsi v $2-0-0$; femora d $0-3-3$, p $0-0-1$. Palps: with base of femora lightly mottled black; clothed in white hairs and scattered light brown bristles. Epigyne (Fig. 4D; 16B).

Dimensions $(\mathrm{mm})$ : total length $11 \cdot 5$; carapace length $4 \cdot 6$, breadth $3 \cdot 54$, height $1 \cdot 6$; abdomen length $7 \cdot 2$; eyes, anterior row $2 \cdot 4$, middle row $2 \cdot 38$, posterior row $2 \cdot 48$; quadrangle length 1.8 (39\% of carapace length). Ratios: AM : AL: PM : PL :: 18:9:7:9; AL-PM-P-L :: 9-13; $\mathrm{AM}: \mathrm{CL}:: 18: \mathrm{ca} .3$. 
VARIATION. Male total length varies from 6.6 to $10.2 \mathrm{~mm}$, carapace length $3.44 .6 \mathrm{~mm}, 10$ specimens; female total length $9 \cdot 4-13.0 \mathrm{~mm}$, carapace length $4 \cdot 0-5 \cdot 5 \mathrm{~mm}, 10$ specimens.

In males the eye region and carapace margins are sometimes heavily tinged black, the development of the retrolateral tibial apophysis also varies, but not to the extent of raising doubts in respect of identification. In females the epigynes show wide differences in appearance and are often plugged; figure 4D shows the kind of epigyne most frequently encountered, other forms are not uncommon.

Distribution. Angola; Cameroon; Ivory Coast; Kenya; North Yemen; Rwanda; São Thomé; Uganda; Zaire.

Material eXAmined. Angola: Cuito, Luimbale, under eucalyptus bark, 1ㅇ, 9.ix.1949, A. de Barros Machado, Ang. 1820.3. Cameroon: River Ja, 1ㅇ, G. L. Bates, purchased off Rosenburg, (BMNH); Edea, 10, [holotype of $H$. camerunensis] Roewer coll., RII/9742/819 (FS, Frankfurt am Main). Ivory Coast: environs of Kotiessou, R. Bandama, 10, 1, 19-20.iv.1952, J. Jezequel, RR.28, (MNHN, Paris). Kenya: J. \& F. Murphy: Kakamega Forest, 1ㅇ, 12.viii.1972; Nairobi, Muthaiga golf course, on gum trees, 3우, ix.1972; Kitale, on banana plant, 1ðิ, 22.vii.1974; Lake Hannington, southern end, from tree, 1ㅇ, 2.viii.1974, (Murphy, private coll.). North Yemen: Wadi Suque, under peeling bark of banana tree, $1400 \mathrm{~m}, 1$, , v.1978, H. Haig-Thomas,

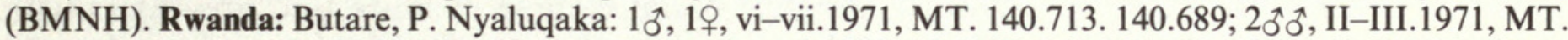
139. 090; 1ㅇ, vi. 1971, MT. 139.162; Butare, R. Kiss, vi.1971, 1ㅇ, MT. 141.196. 1ㅇ, MT. 141.191; Environs Lake Ihema, R. Kiss, 14-18.vii.1969, 2우, MT. 136.316, 1ð, MT. 136.299. (MRAC, Tervuren). São Thomé:

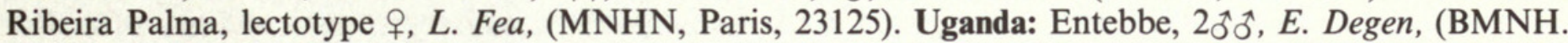
1906.3.28.58-360, part). Zaire: Poko, [holotype ô of $H$. vidua, (AMNH, New York); Kivu, Irangi, 2qo+, vi.1969, S. Orts, MT. 136.166; Tshuapa, Boende, 1ㅇ, x.1969, J. Hauwaerts, MT. 136.145; Flandria, 1 , $R$. P. Hulstaert, MT. 12056; Kutshuuree, iii.1938, 1, J. Ghesquière, MT. 1346, (MRAC, Tervuren).

Note. Dyals description of $H$. vidua (Dyal, 1935) does not appear to fit this species, in particular 'First pair of legs are thick, and reddish brown, patellae are longer than is usually the case in spiders, tibiae are short and swollen and tarsi are short and slender'. The record from Pakistan has therefore not been included in the distribution list.

\section{Holcolaetis zuluensis Lawrence}

(Figs 6, 16C)

Holcolaetis zuluensis Lawrence, 1937: 255. ㅇ LECTOTYPE, 2우 PARALECTOTYPES (here designated) South Africa (NM. Pietermaritzburg) [examined]. Roewer, 1954: 937; 1965: 28. Bonnet, 1957: 2223. Prószyński, 1971: 418. Clark, 1974: 16. Cutler, 1976: 132.

[H. xerampelina: Lessert, 1925a: 432, 433; 1925b: 342; 1927: 427. Roewer, 1965: 24. Misidentification].

REMARKs.The majority of references to $H$. xerampelina Simon almost certainly refer to $H$. zuluensis Lawrence, see remarks p. 254.

Diagnosis. Close to $H$. vellerea, but easily separated by the sinuous tip of the functional conductor and presence of flanges on the palpal retrolateral tibial apophyses in males (Fig. 6A). Females are distinguished by the presence of dark patches anterior to the rounded depressions surrounding the copulatory openings (Figs $6 \mathrm{E}-\mathrm{G}$ ).

Female LeCtotype, in good condition. Carapace: profile typical of genus; dark reddish brown with blackened iridescent eye region and a broad pale orange-brown thoracic band tapering towards posterior margin; generally clothed in greyish hairs with whitish ones in eye region and thoracic band; also, on margins and submargins thin bands of white hairs, the latter contiguous with and becoming broader towards clypeus. Eyes: laterals with black surrounds; fringed by whitish and golden hairs. Clypeus: densely clothed in long buff hairs. Chelicerae: dark reddish orange, basal part of facies clothed in buff hairs overlayered by clypeal setae; promargin with four teeth, retromargin with eight (six to nine in other specimens). Maxillae: dark reddish orange with pale yellow inner distal margins. Labium: dark reddish orange. Sternum: orange-brown with darker margins that are wider and slightly more conspicuous opposite anterior coxe; clothed in 
scattered fine brown hairs with whitish ones on margins. Coxae: first pair dark reddish orange, rest orange-brown. Abdomen: dorsum yellow-brown lightly tinged black, clothed in dark amber hairs with broad yellow-brown dentate band thinly clothed in pale amber hairs and scattered bristles; pustuliform field obscure; venter pale yellowish with vague longitudinal grey bands and four rows of minute spots; spinnerets pale orange-brown lightly tinged black. Legs: legs I dark orange-brown suffused black with paler tarsi and metatarsi, fringed ventrally with brownish hairs; legs II as I, but paler with sparser fringes; other legs orange-brown with vague blackish annuli; also, on all legs scattered transversely set patches of white hairs. Spination of legs I: femora d 0-1-9, p 0-1-1. Palps: yellow-brown to orange-brown distally with sooty annuli on tarsi. Epigyne (Fig. 6G): note inner lining of the introductory ducts appears to be displaced in lactic acid preparations (Figs 6C, D; 16C).

Dimensions $(\mathrm{mm})$ : total length 12.5 ; carapace length 4.96 , breadth 3.92 , height 1.84 ; abdomen length 7.36; eyes, anterior row $2 \cdot 76$, middle row $2 \cdot 68$, posterior row $2 \cdot 76$; quadrangle length 1.96 (39\% of carapace length). Ratios: AM : AL: PM : PL :: $20: 11: 7: 10 \cdot 5$; AL-PM-PL :: 12-15; $\mathrm{AM}: \mathrm{CL}:: 20$ : ca.3.

MALE from Pietermaritzburg, in good condition. Carapace: similar to female, but darkerbrownish black with broad dark reddish thoracic band; clothed in black and grey hairs with golden ones in and around eye region and whitish ones on thoracic band; marginal bands as in female. Eyes: fringed by golden and brown hairs. Clypeus: black haired. Chelicerae: blackish red with scattered fine black hairs; promargin with five teeth, retromargin with seven. Maxillae and labium: reddish black the former with light yellowish inner distal margins. Sternum: dark orange-brown with darker margins; clothed in scattered black and marginal white hairs. Coxae: orange-brown first pair darkest. Abdomen: densely clothed in black hairs with broad central band comprised of creamy yellow hairs; pustuliform field relatively conspicuous; venter brownish black, clothed in short black hairs with vague longitudinal whitish bands laterally. Legs: long and slender in respect of female and also generally hirsute; legs I brown-black with dense black fringes and patches of recumbent white hairs on prolateral surface of patellae and basal prolateral face of metatarsi; legs II with orange-brown tarsi, other segments brown-black with vague paler markings, generally clothed in long black hairs forming dense fringes on lower retrolateral face of femora and patellae and venter of tibiae; also present usual scattered patches of recumbent white hairs especially on patellae and femora; other legs similar, but with less conspicuous fringes and pale metatarsi becoming blackish distally. Spination of legs I: femora d 0-6-2. Palp: (Fig. 6A, B).

Dimensions $(\mathrm{mm})$ : total length $11 \cdot 2$; carapace length $5 \cdot 68$, breadth $4 \cdot 16$, height $2 \cdot 16$; abdomen length 5.68; eyes, anterior row 3.02 , middle row $2 \cdot 88$, posterior row $2 \cdot 92$; quadrangle length $2 \cdot 24$ (39\% of carapace length). Ratios: AM : AL : PM : PL :: 21.5: $12: 8: 11$; AL-PM-PL :: 13-17; $\mathrm{AM}: \mathrm{CL}:: 21 \cdot 5$ : ca. 5 .

VARIATION. Male total length varies from 8.7 to $11.2 \mathrm{~mm}$, carapace length $4.22-5.68 \mathrm{~mm}$, five specimens; female total length $9 \cdot 36-15 \cdot 2 \mathrm{~mm}$, carapace length $4.04-6.16 \mathrm{~mm}, 10$ specimens.

Variation in the appearance of the epigyne is clearly evident from the type series (Fig. 6E-G).

Distribution. South Africa; Tanzania.

Material eXamined. South Africa: Natal, no other data: 5ㅇ, 2 juveniles, Ch. Martin, (MNHN, Paris.

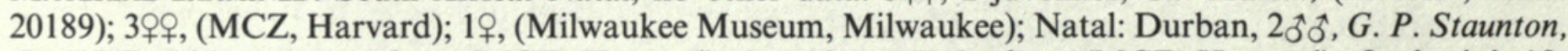
(BMNH); 3우, J. F. Quekett, (MCZ, Harvard); 10, 1ㅇ, J. F. Quekett, (MCZ, Harvard); Otobotini, 1ㅇ, vii.1938, (NM, Pietermaritzburg); Pietermaritzburg, 10, 1917, C. Akerman, (NM, Pietermaritzburg, 2430); Zululand, Kosi Bay, lectotype + , paralectotypes 2o+9, vii.1936 (NM, Pietermaritzburg, 140); Willow Fountain, Pietermaritzburg, iv.1958, 10ิ, (NM, Pietermaritzburg, 6987); Transvaal, Kruger N. P., Parfuri, 2우, H. Braak, (BMNH). Tanzania: Ngare Nanyuki 1ోో, 1ㅇ, Y. Siostedt, (NR, Stockholm).

\section{Holcolaetis albobarbata Simon}

(Figs 7, 8, 16D)

Holcolaethis albobarbata Simon, 1909 (1910): 79. LECTOTYPE + , PARALECTOTYPE designated) Angola, (MNHN, Paris) [examined]; [Holcolaethis, lapsus for Holcolaetis]. 

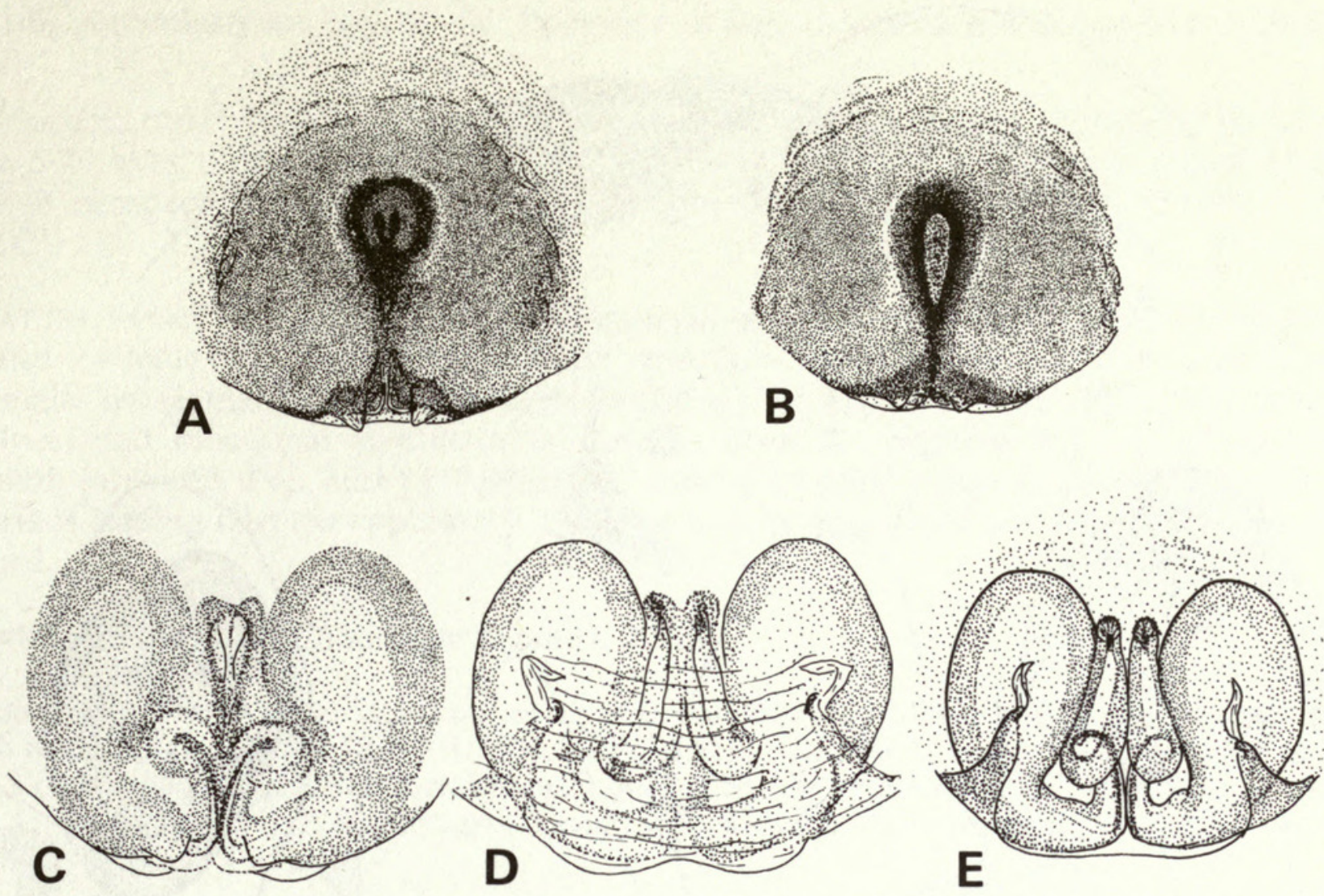

Fig. 7 Holcolaetis albobarbata Simon, o: A, lectotype epigyne; B, paralectotype epigyne; C-E, paralectotype vulva: C, outer view, connective tissue in situe; $\mathrm{D}$, inner view, connective tissue in situe; $\mathrm{E}$, inner view, connective tissue removed.

Holcolaetis albobarbata: Lessert, 1925a: 434. Roewer, 1954: 937; 1965: 25. Bonnet, 1957: 2222. Prószyński, 1971: 417. Clark, 1974: 16.

[Holcolaethis strandi: Caporiacco, 1941: 135, misidentification].

REMARKs. The original description of $H$. strandi Caporiacco was based on a juvenile and as a consequence it is treated here as a species incertae sedis. A subsequent description (Caporiacco, 1941) based on an adult female, which has been re-examined, is clearly conspecific with $H$. albobarbata.

Roewer (1965) figured the epigyne of both $H$. strandi and $H$. albobarbata, of these, his figure of strandi is a poor copy of Caporiacco's original, whereas the albarbata [sic] figure does not agree with any known species of Holcolaetis. Clark, in correspondence, reached the same conclusion as the present author, namely that Roewer's salticid studies are crude and unreliable.

DiaGNOSIS. Similar to $H$. clarki, but separated by the absence of well developed flanges on the palpal retrolateral tibial apophysis in males (Fig. 8B,F) and by the more or less ovate depression surrounding the copulatory openings in females (Fig. 7A,B).

FEMAle LeCTOTYPe, in poor condition. Carapace: profile typical of genus; dark reddish with vague broad dull orange band on thoracic part; irregularly clothed in whitish pubescence (rubbed). Eyes: laterals with black surrounds; fringed by whitish hairs. Clypeus: densely white haired. Chelicerae: dark reddish with short white hairs basally and scattered long pale golden ones elsewhere; promargin with six teeth, retromargin with seven. Maxillae and labium: reddish orange with inner distal margins of maxillae and labial tip whitish yellow. Sternum: pale yellowish orange with darker margins; thinly clothed in fine pale yellowish hairs. Coxae: first pair light reddish orange, others yellowish orange. Abdomen: damaged and badly rubbed; greyish white with patches of whitish and amber mottling clothed in amber and light golden hairs, basic markings characteristic of genus. Legs: legs I dark reddish orange with fringe of amber hairs on venter of tibiae and patellae; other legs generally pale yellowish with dark orange markings forming vague annuli on tibiae III-IV and metatarsi IV. Spination of legs I: femora d 0-2-2, p 0-1-2. 

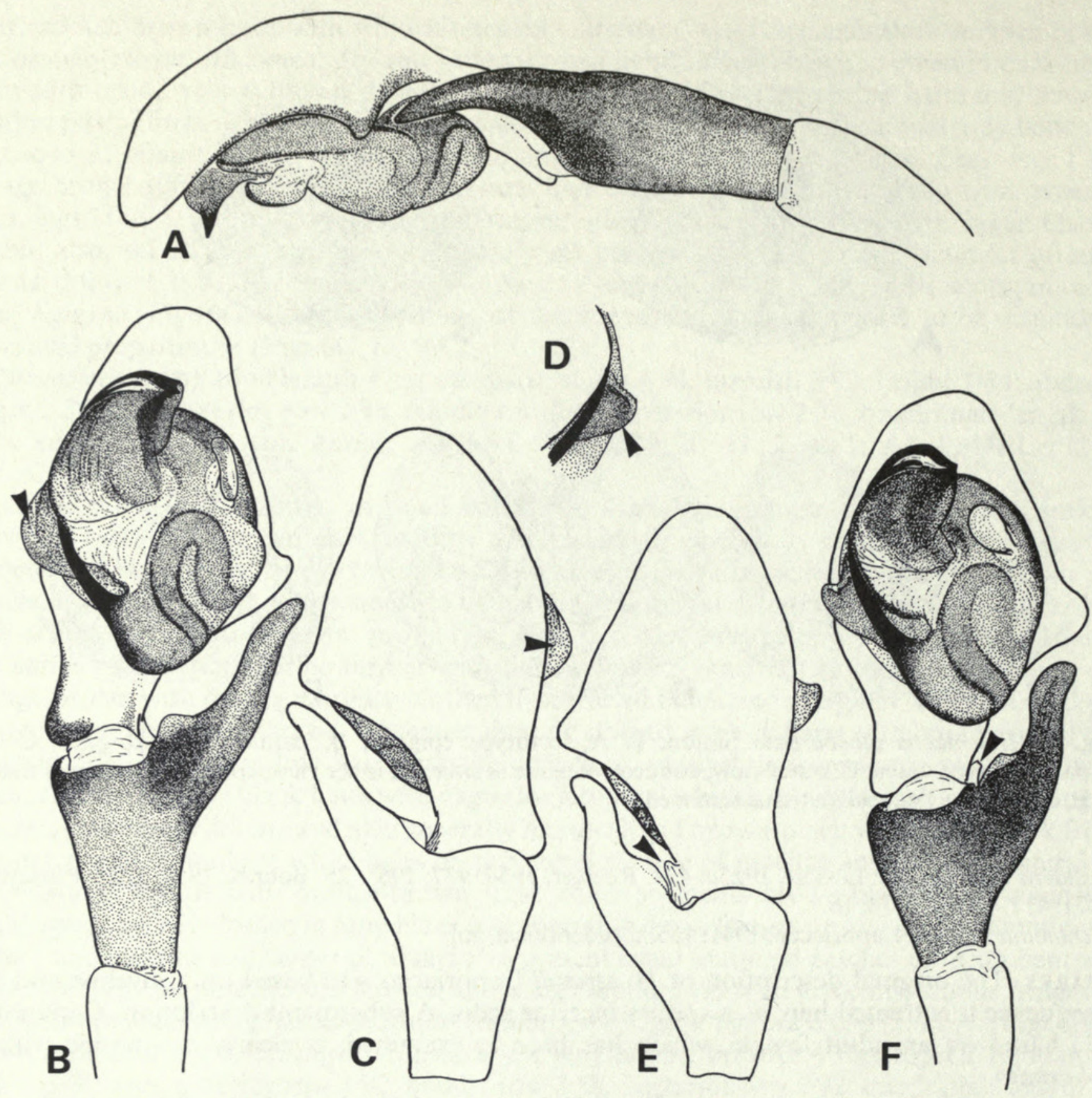

Fig. 8 Holcolaetis albobarbata Simon, ô: A-C, left palp of Cameroon specimen; A, retrolateral view; B, ventral view; C, dorsal view - cymbial spur lacking. D-F, palps of Ugandan specimen: D, tegular flange of right palp, ventral view; E, left palp, dorsal view-cymbial spur present, arrowed; F, left palp, ventral view, cymbial spur, arrowed.

Palp: femora and patellae pale yellowish orange, remaining segments dark reddish; clothed in white and golden hairs. Epigyne (Fig. 7A).

Dimensions $(\mathrm{mm})$ : total length ca. 14.0; carapace length $5 \cdot 28$, breadth $3 \cdot 84$, height $2 \cdot 0$; abdomen length ca. $8 \cdot 8$; eyes, anterior row $2 \cdot 9$, middle row $2 \cdot 88$, posterior row $2 \cdot 96$; quadrangle length 2.08 (39\% of carapace length). Ratios: AM : AL : PM : PL :: 21.5: $12: 8: 12$; AL-PM$\mathrm{PL}:: 14-18 ; \mathrm{AM}: \mathrm{Cl}:: 21 \cdot 5: \mathrm{ca} .4 \cdot 5$.

MALE from Cameroon, in fair condition. Carapace: profile typical of genus; dark orange-brown tinged black especially in eye region; rubbed. Eyes: laterals with black surrounds. Clypeus: clothed in pale grey/brown hairs. Chelicerae: orange-brown faintly tinged black; rubbed; promargin with six teeth, retromargin with nine. Maxillae: orange-brown with whitish yellow inner margins. Labium: dark orange-brown. Sternum: yellow-brown with darker margins. Coxae: first pair orange-brown, rest paler. Abdomen: rubbed; pale yellow lightly mottled black on sides, basic markings typical of genus; spinnerets yellow-brown tinged black. Legs: with pale golden fringes on venter of patellae and tibiae of legs I; generally yellow-brown with apices of metatarsi 
blackish, particularly on legs III-IV. Spination of legs I: femora d 0-2-3, p 0-2-2. Palp (Fig. $8 \mathrm{~A}-\mathrm{C})$.

Dimensions $(\mathrm{mm})$ : total length $10 \cdot 24$; carapace length $4 \cdot 44$, breadth $3 \cdot 12$, height $1 \cdot 68$; abdomen length 5.76; eyes, anterior row 2.52, middle row 2.44, posterior row 2.48; quadrangle length 1.9 (42\% of carapace length). Ratios: AM : AL : PM : PL :: 20:10:7: 10; AL-PM-PL :: 11-14·5; $\mathrm{AM}: \mathrm{CL}:: 20: 2$.

VARIATION. Males vary from 9.84 to $10.8 \mathrm{~mm}$ total length, $4.16-4.56 \mathrm{~mm}$ carapace length, three specimens; female total length $12.5-14.0 \mathrm{~mm}$, carapace length $4.88-5.02 \mathrm{~mm}$, three specimens.

In males the tegular flange is sometimes damaged (Fig. 8F) the profile of the retrolateral tibial apophysis and functional conductor is variable; also, the peg-like spur on the base of the cymbium (arrowed, Fig. 8E,F) is apparently lacking in some palps. In females the margins of the orifice leading into the copulatory openings may be ill-defined and obscured by detritus or plugged.

\section{DistriBution. Angola; Cameroon; Uganda; Zaire.}

Material examined. Angola: Landana, lectotype + , paralectotype + , (MNHN, Paris. 20206). Cameroon: Benito River, 1бิ, G. L. Bates, (BMNH. 1898.5.5.126-137 part); Kribi, G. L. Bates, (BMNH. 1907.6.27.1-82 part). Uganda: $G$. $O$. Evans, Ruwenzori Expedition, 10, beating vegetation, chiefly grassland on margin of dense forest, 10 miles NNE Bundibugyo, 26.viii.1952, (BMNH). Zaire: Kisantu, 1, P. Vanderyst, 1927, MT. 12059 (MRAC, Tervuren).

NotE. The male described above probably belongs here, but this should be confirmed since there is little to choose between the male specimens listed above and the males assigned to $H$. clarki sp.n. There is an overlap in their distribution and they may have been mismatched.

\section{Holcolaetis clarki sp. n.}

(Figs 9, 10, 16E)

DiaGNOSIS. Close to $H$. albobarbata, but separated by the presence of well-developed flanges on the retrolateral tibial apophysis in males (Fig. 10A, D) and by rounded depressions surrounding the copulatory openings in females (Fig. 9C, D).

FeMAle hOLOTYPE, in good condition. Carapace (Fig. 9A, B): chestnut brown tinged black in eye region with irregular light orange-brown margins and central band on thoracic part; eye region clothed in greyish and dull amber hairs with whitish grey ones on thoracic band and dark brownish ones thinly interspersed with white hairs on the sides, the brown hairs grading to black adjacent to marginal bands which are clothed in white hairs. Eyes: laterals with black surrounds; fringed in light brownish and dull amber hairs with white ones between anterior medians and on lower rims of anterior laterals. Clypeus: clothed in some black and amber hairs with white ones in lower space between anterior median eyes and below anterior laterals - the origin of the white marginal bands; also, a few long white scattered hairs on lower margin. Chelicerae: orange-brown lightly tinged black; shiny; clothed in short white and black hairs basally with long fine brownish ones distally; teeth not examined. Maxillae and labium: orange-brown with inner distal margins of maxillae and labial tip whitish yellow. Sternum (Fig. 10E): light yellow-brown with darker margins; shiny; thinly clothed in whitish and pale brown hairs. Coxae: pale yellowbrown. Abdomen: generally pale yellow with broad dorsal dentate band clothed in pale brownish lanceolate hairs with dark brownish and black hairs laterally, the latter forming flecks on upper sides; venter flecked and spotted with brown-black hairs; also, from epigyne to spinnerets two vague and rather scanty bands of greyish lanceolate hairs; spinnerets dark yellow-brown tinged with some black. Palps: femora and patellae whitish yellow, tibiae and tarsi light to dark orange-brown; clothed in long white hairs. Legs: legs I femora yellow-brown with sooty markings, patellae and tibiae brown with lighter patches, metatarsi and tarsi light orange-brown with 

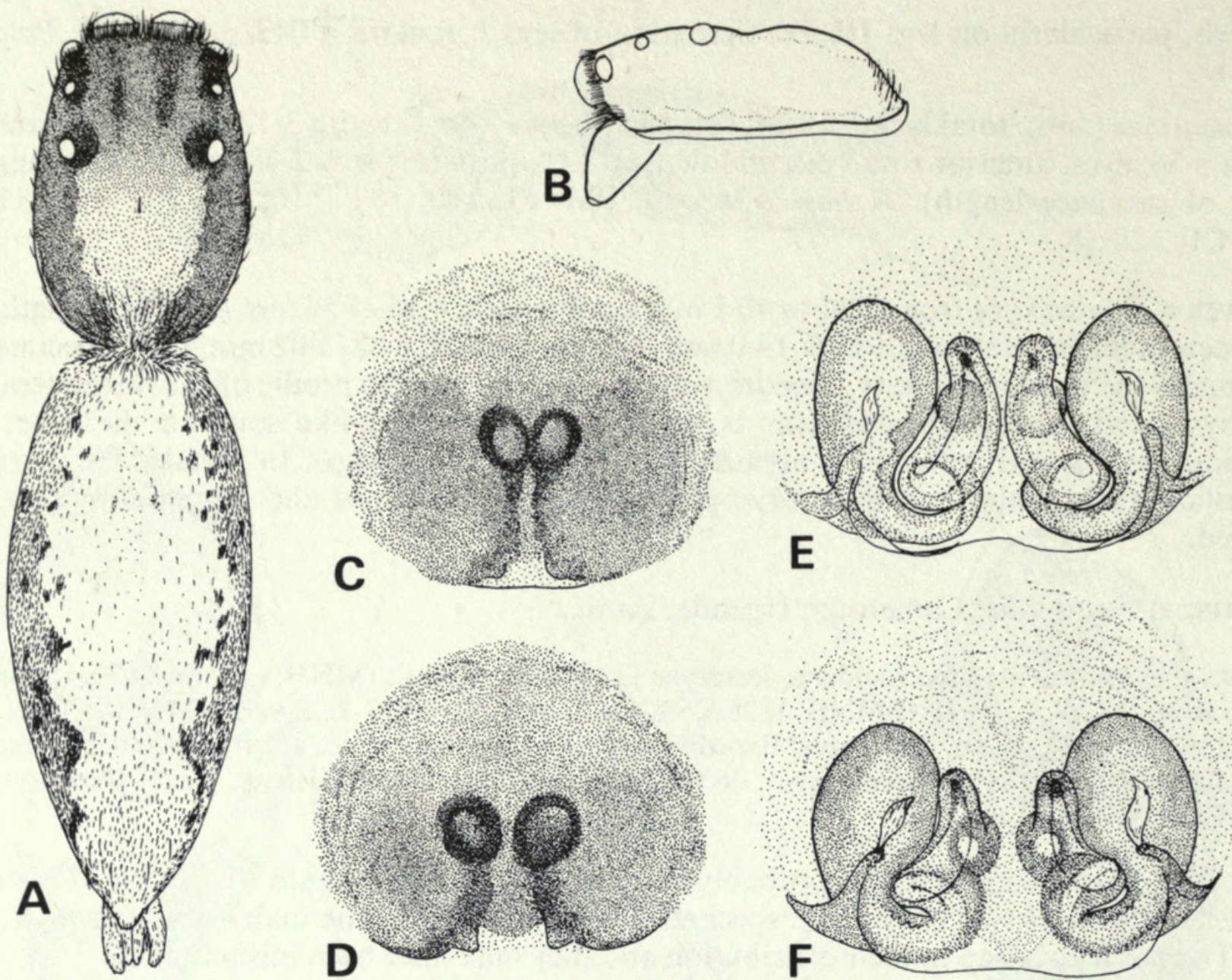

Fig. 9 Holcolaetis clarki sp. n., holotype q: A, dorsal view; B, carapace, lateral view; C, epigyne. D, epigyne, paratype from Cameroon; E, vulva, inner view-Cameroon paratype; $\mathrm{F}$, vulva, inner view-Ghanain paratype.

apices of former segment sooty; generally clothed in blackish hairs forming scanty ventral fringes on tibiae and patellae; also, scattered white hairs especially on femora forming sparse recumbent tufts; other legs generally light yellow-brown with blackish markings. Spination of legs I: femora d 0-2-3, p 0-1-1. Epigyne (Fig. 9C).

Dimensions $(\mathrm{mm})$ : total length $12 \cdot 3$; carapace length $4 \cdot 4$, breadth $3 \cdot 08$, height $1 \cdot 64$; abdomen length $7 \cdot 84$; eyes, anterior row $2 \cdot 44$, middle row $2 \cdot 4$, posterior row $2 \cdot 48$; quadrangle length 1.92 (43\% of carapace length). Ratios: AM : AL : PM : PL :: 19: $10: 7: 11$; AL-PM-PL :: 11-14; $\mathrm{AM}: \mathrm{CL}:: 19: 5$.

MALE PARATYPE, in poor condition. Carapace: profile typical of genus; dark orange-brown tinged black in eye region with vague paler band on thoracic part and indistinct light marginal bands; largely rubbed, otherwise clothed in grey/pale amber hairs with white ones on margins. Eyes: laterals with black surrounds; fringed by whitish hairs with dull amber ones around lower rims of anterior row. Chelicerae: dark brownish orange lightly tinged black with scattering of dark amber hairs basally; otherwise rubbed; promargin with seven teeth, retromargin with eight. Clypeus: clothed in amber hairs. Maxillae: orange-brown with paler distal margins. Labium: orange-brown tinged black. Sternum (Fig. 10F): pale yellow-brown with darker margins; shiny. Coxae: pale yellow-brown; shiny. Abdomen: rubbed; a broad pale yellow dentate band dorsally with blackish mottling on sides; ventrally a vague broad longitudinal grey band containing two darker lines. Legs: legs I-II orange-brown tinged black, first pair with remnants of ventral amber fringes; other legs yellow-brown with blackish markings. Spination of legs I: femora p $0-1-1$; d 0-2-2. Palp (Fig. 10A-C). 

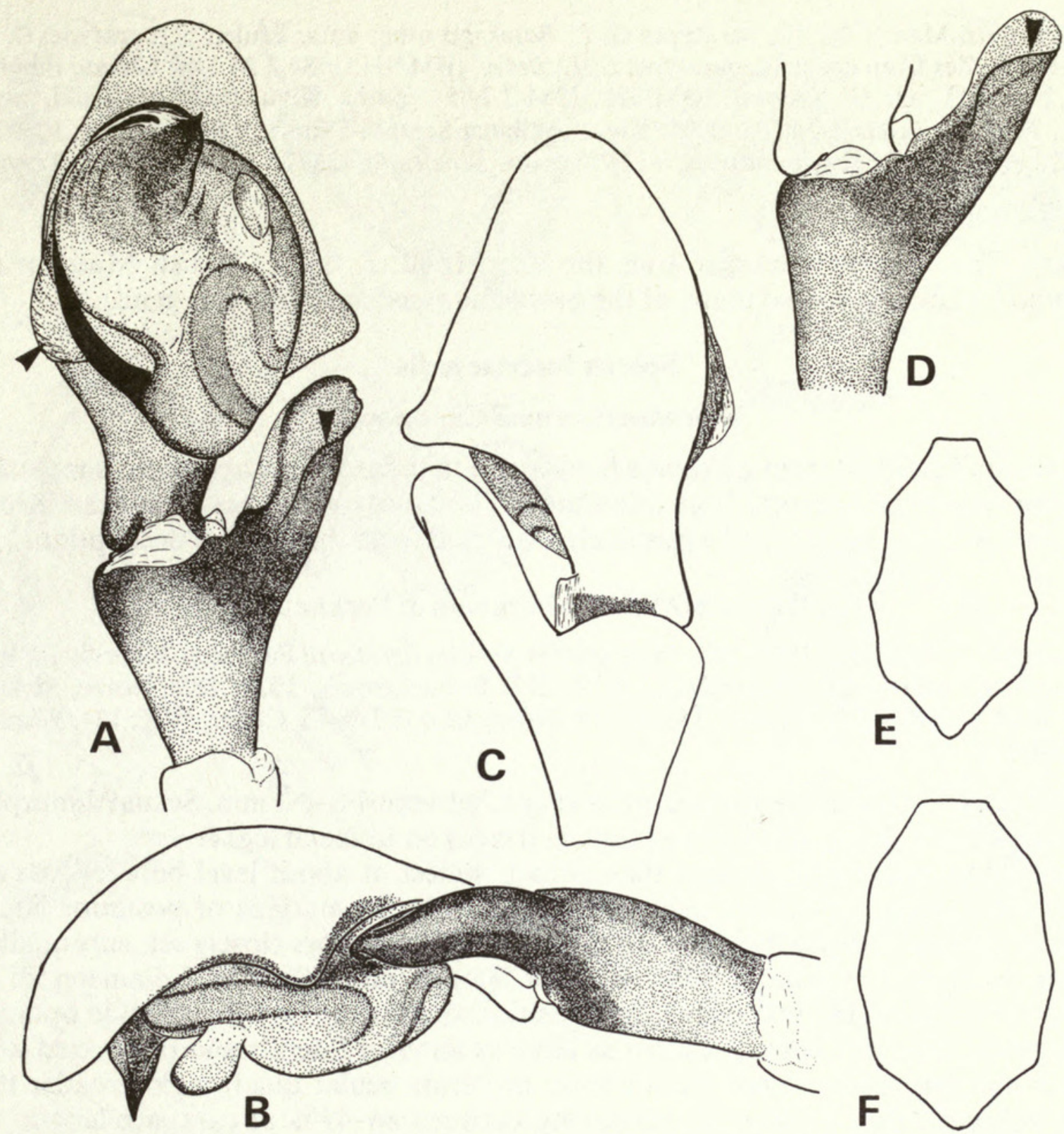

Fig. 10. Holcolaetis clarki sp. n., paratype ${ }^{\dagger}$ from Cameroon 'no other data': A, palp, ventral view; B, palp, retrolateral view; C, palp, dorsal view; F, sternum. D, ô from Cameroon, Kribi River, palpal tibia ventral view. E, holotype , sternum.

Dimensions $(\mathrm{mm})$; total length $7 \cdot 44$; carapace length $3 \cdot 24$, breadth $2 \cdot 24$, height $1 \cdot 24$; abdomen length $4 \cdot 24$; eyes, anterior row 1.9 , middle row 1.88 , posterior row 1.94; quadrangle length 1.4 (43\% of carapace length). Ratios: AM : AL : PM :PL :: 15·5: 8.5: $5: 8$; AL-PM-PL :: 9-11; $\mathrm{AM}: \mathrm{CL}:: 15 \cdot 5: 3$.

VARIATION. Another male measures $8.8 \mathrm{~mm}$ total length, $4.32 \mathrm{~mm}$ carapace length; females vary from $11 \cdot 3-13.6 \mathrm{~mm}$ total length, $3.9-5.36 \mathrm{~mm}$ carapace length, seven specimens.

Females that have been preserved for longer periods than the specimen described above are somewhat redder in colour and the patterns are less distinctive. The vulvae also vary in appearance, due probably to differences in the size and disposition of the introductory ducts. In one female from Angola the clypeus is clothed in white hairs. In males the palp of a relatively large specimen has more pronounced flanges on the retrolateral tibial apophysis (Fig. 10D), possibly an allometric growth character.

Distribution. Angola; Cameroon; Ghana; Zaire.

Material eXAMined. Angola: environs of Dundo, forest zone, R. Luachimo, under bark, $q$ paratype, 6.vii.1948, A. de Barros Machado, Ang. 829.3. Cameroon: Edea, \& paratype, Roewer Coll. RII/9270/591, 
(FS, Frankfurt am Main); 1ð^, 1, paratypes G. L. Bates, no other data; Efulen, ㅇ, paratype, G. L. Bates, Kribi River, 25 miles from coast, ơ, paratype, G. L. Bates, (BMNH. 1984.2.24.1.4). Ghana: Bibianaba, 1ㅇ, paratype, 29.x.1911, H. G. Spurrell, (BMNH. 1984.2.24.5). Zaire: Kivu, forêt de Visiki, holotype ơ, 27.xii.1971, R. P. M. Lejeune, MT. 140905; Kivu, confluent Semliki-Djuma, o paratype, R. P. M. Lejeune, MT. 135.625; Mongbwalu, 2 q + paratypes, vii.1973, Mme Scheitz, MT. 1575-1578, (MRAC, Tervuren).

REMARK. See note. p. 260.

ETymology. This species is named after the late Mr D. J. Clark, British Museum (Natural History) who had clearly solved many of the problems associated with this genus.

\section{Species incertae sedis}

\section{Holcolaetis strandi Caporiacco}

This species was described from a juvenile female and to judge from Caporiacco's measurements, the specimen was several moults from adulthood. The holotype has not been examined and the species cannot at the present time be positively identified from the original description.

\section{Genus SONOITA Peckham \& Peckham}

Sonoita Peckham \& Peckham, 1903: 183. Type species Sonoita lightfootii Peckham \& Peckham, by original designation and monotypy. Waterhouse, 1912: 277. Petrunkevitch, 1928: 182. Neave, 1940, iv: 224. Roewer, 1954: 937; 1965: 19. Bonnet, 1958: 4019. Prószyński, 1971: 475. Cutler, 1976: 134. Wanless, 1982: 264; 1984a: 138.

DefinItion. Spiders of medium size, i.e. total length between 4.0-8.0 mm. Sexual dimorphism not marked, only known species with strong ventral fringes on tibiae of legs I.

Carapace: moderately high, longer than broad, widest at about level between coxae II-III; fovea moderately long, sulciform, apex at level of posterior margins of posterior lateral eyes. Eyes: with moderately strong lenses set on low tubercles; anteriors closely set, subequally spaced with apices procurved in frontal view; anterior laterals more than half diameter of anterior medians; posterior medians relatively large, positioned closer to and just outside optical axis of anterior laterals; posterior laterals almost as large as anterior laterals and positioned well inside of carapace margins when viewed from above; posterior ocular quadrangle broader than long and wider behind; entire quadrangle occupying between $46-49 \%$ of carapace length. Clypeus: low. Chelicerae: moderately robust; facies more bulbous in females; fang moderately strong and curved; promargin with three to five teeth, retromargin with five or six. Maxillae: long and parallel with rounded outer distal margins. Labium: slightly longer than broad and about half maxillae length. Sternum: elongate scutiform in female, evidently similar in males, but partly obscured by coxae in available specimens. Coxae: fourth pair noticeably larger than I-III. Abdomen: elongate ovoid, sometimes marked with subcutaneous quanin (?) artifact of preservation; basic pattern, of only unrubbed specimen, comprised of paler longitudinal dorsal band containing chevrons posteriorly and flanked by flecks on either side; pustuliform field comprised of scattered pustuliform organs obscured by setae; spinnerets moderately long, posteriors and anteriors unequally robust, medians shorter and more slender; tracheal system not examined, insufficient material, spiracle presumably an indistinct slit near base of anterior spinnerets; former position of colulus represented by scanty group of setae. Legs: moderately long and slender with strong ventral fringes on tibiae and retroventral surface of femoral apices; spines moderately strong and numerous: in male present on metatarsi, tibiae, patellae and femora of all legs, in females similar, but legs I-II with femoral spines only; claws smooth or pectinate; tufts present; scopulae absent.

Epigyne: small and structurally similar to Holcolaetis; posterior margin with delicate flanges; copulatory openings somewhat disc-like, but indistinct; introductory ducts broad and looped; glandular appendices not evident; spermathecae apparently subovoid, but precise form uncertain as they blend and appear to fuse with the introductory ducts (Figs $11 \mathrm{~K}, \mathrm{~L}$ ); fertilisation ducts slender, leaf-like and apparently supported as in Holcolaetis.

Male palps: essentially as in Holcolaetis except retrolateral tibial apophysis broad and fan-like; expanded palps not examined-insufficient material. 

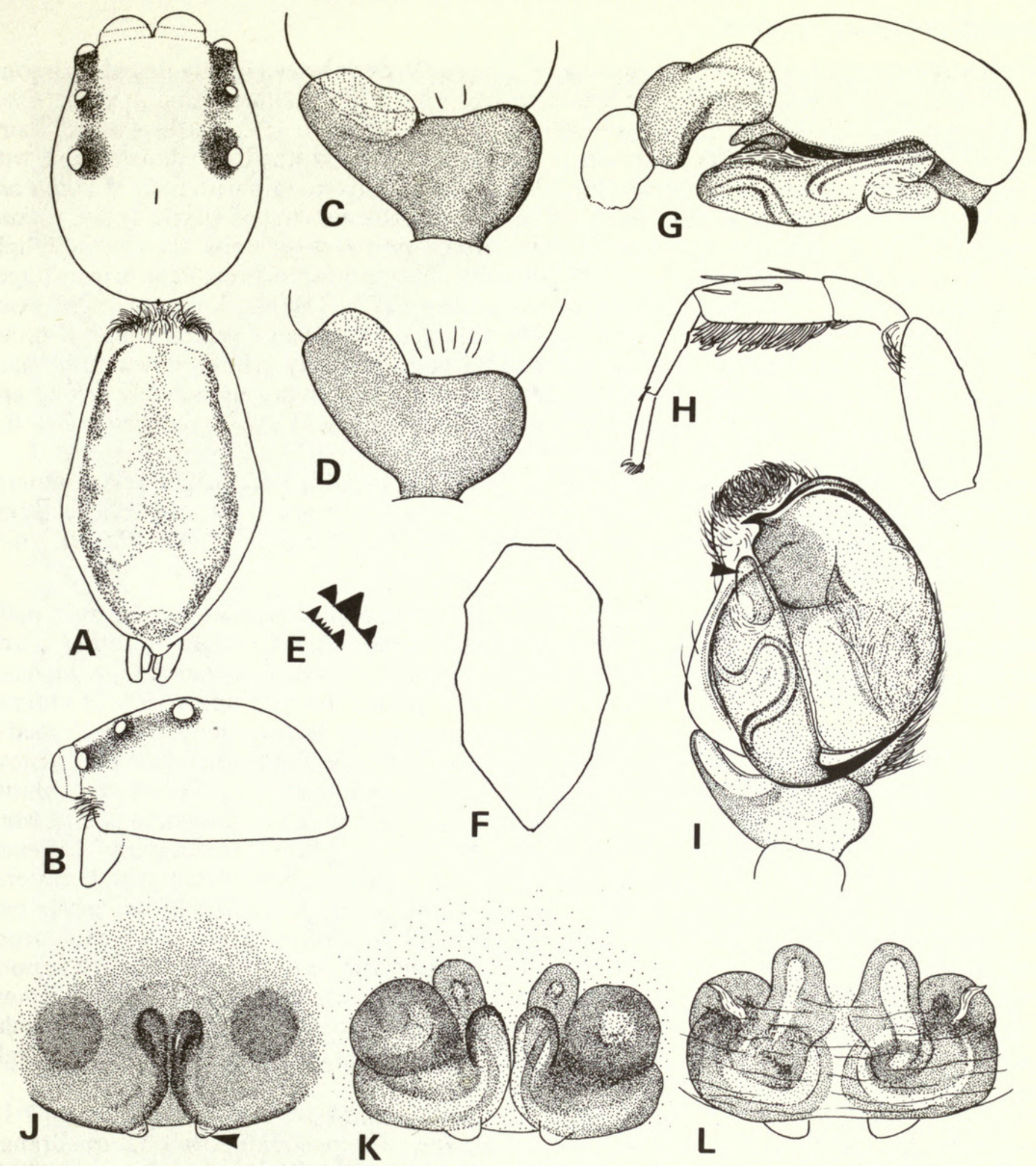

Fig. 11 Sonoita lightfooti Peckham \& Peckham, holotype $\widehat{乛}:$ A, dorsal; B, carapace, lateral view; C, palpal tibia, dorsal view; E, cheliceral teeth; G, palp, retrolateral view; H, leg I; I, palp, ventral view. + from Ivory Coast: F, sternum; J, epigyne; K, vulva, outer view; L, vulva, inner view.

DIAGNOSIs. From Holcolaetis by the moderately high carapace and from all other salticids by the combination of large posterior median eyes, bowl-like median apophysis in males (arrowed, Fig. 11I) and translucent epigynal flanges in females (arrowed, Fig. 11J).

AfFinities. See discussion on Holcolaetis.

Sonoita lightfooti Peckham \& Peckham

(Figs 11, 13, 14, 16F)

Sonoita lightfootii Peckham \& Peckham, 1903: 184. Holotype ${ }^{\circ}$, Cape Colony, (MCZ, Harvard) [examined]. Roewer, 1954: 937; 1965: 20. Cutler, 1976: 134.

S. lightfooti: Bonnet, 1958: 4091. Prószyński, 1971: 75. 
Diagnosis. As generic diagnosis.

MALE HOLOTYPE, in poor condition. Carapace (Fig. 11A, B): dark brown lightly tinged with some black in eye region; rubbed, except for scattered fine whitish/pale amber hairs on sides. Eyes: laterals with black surrounds; fringed by whitish hairs. Clypeus: clothed in dirty white hairs. Chelicerae: brownish with paler inner distal margins; basally clothed in whitish hairs with scattered amber hairs elsewhere; promargin with three teeth, retromargin with two. Maxillae and labium: brownish tinged black with paler tips. Sternum: brownish tinged black; shiny. Coxae: brownish. Abdomen: contents shrunken, original pattern indistinct generally blackish with light brown markings and tuft of amber and whitish hairs anteriorly; spinnerets light brown tinged with some black. Legs: moderately long and slender; legs I (Fig. 11H) dark amber tinged black except for tarsi and metatarsi which are yellow-brown; tibiae I with dense ventral fringe of amber spatulate setae; other legs, excluding missing second pair, generally yellow-brown with vague blackish mottling and indistinct annuli on apices of metatarsi; spines moderately strong and numerous. Spination of legs I: metatarsi v $2-0-1, \mathrm{~d} 1-0-2$; tibiae d 3-1-2; patellae p $0-1-0, \mathrm{r}$ 0-1-0; femora d 0-2-3, d 0-2-3, p 0-0-1. Palp (Fig. 11C, G).

Dimensions $(\mathrm{mm})$ : total length $4 \cdot 5$; carapace length $2 \cdot 08$, breadth 1.56 , height 1.08 ; abdomen length 2.44 ; eyes, anterior row 1.2 , middle row 1.22 , posterior row 1.32 ; quadrangle length 0.96 (46\% of carapace length). Ratios: AM : AL : PM : PL :: $9: 5: 3 \cdot 5: 5$; AL-PM-PL :: 6-9; $\mathrm{AM}: \mathrm{CL}:: 9: ? ?$ ?

Female from Ivory Coast, in fair condition, formerly undescribed. Carapace: profile as in male; orange-brown lightly tinged with some black especially in eye region; clothed in rather coarse white hairs with pale golden ones forming vague longitudinal bands in eye area. Eyes: laterals with black surrounds; fringed by white hairs with pale golden ones on upper rims of anterior medians. Clypeus: covered in long white hairs. Chelicerae: orange-brown; shiny; thinly clothed in white and fine pale brown hairs; pro- and retromargin with five teeth. Maxillae: pale yellowbrown with whitish inner distal margins. Labium: yellow-brown lightly tinged black with whitish tip. Sternum (Fig. 11F): light orange-brown suffused black; shiny thinly clothed in coarse white hairs with fine pale hairs centrally. Coxae: IV clearly largest; pale yellow-brown; shiny. Abdomen: greyish yellow with yellow subcutaneous quanin dorsally; clothed above in white and scattered dark amber hairs forming flecks on sides-basic pattern rather as in Holcolaetis; venter pale yellow with broad blackish band containing four rows of pale spots. Legs: legs I with strong fringes of grey/black lanceolate hairs on underside of tibiae and retroventral surface of femoral apices; general colouration of tarsi and metatarsi yellow-brown, tibiae, patellae and femora orange-brown tinged black; other legs yellow-brown with blackish markings forming irregular annuli; clothed in scattered white hairs. Spination of legs I: femora p 0-0-1, d 0-2-2. Palps: light yellow-brown with sooty markings. Epigyne (Figs 11J-L; 16F).

Dimensions $(\mathrm{mm})$; total length ca. $5 \cdot 6$ (bent); carapace length $2 \cdot 16$, breadth $1 \cdot 64$, height $1 \cdot 12$, abdomen length $3 \cdot 4$; eyes, anterior row $1 \cdot 24$. middle row, $1 \cdot 2$, posterior row $1 \cdot 32$; quadrangle length 1.06 (49\% of carapace length). Ratios: AM:AL:PM:PL:: 9.5:5:3:5; AL-PMPL :: 7-9; AM : CL :: 9·5:3.

VARIATION. Another male measures ca. $4.05 \mathrm{~mm}$ total length $1.96 \mathrm{~mm}$ carapace length; whereas a damaged female measures ca. $5 \cdot 5 \mathrm{~mm}$ total length, $2 \cdot 28 \mathrm{~mm}$ carapace length.

The abdominal pattern of a second Ivory Coast female differs from that described above in that it lacks conspicuous yellow quanin and as such resembles the holotype male. In males there are differences in the shape of the retrolateral tibial apophyses (Fig. 11C, D) which are not considered to be significant in view of overall similarities in other characters.

Distribution. Ivory Coast; South Africa.

MATERIAL EXAMINED. Ivory Coast: River Bandama, environs Kotiessou, from a tree Pilostigma thonningii, Lamotte coll., PNB 179, 1б; PNB 146, 2oㅇ, PNB 174, i juv. (MNHN, Paris). South Africa: Cape Colony, holotype $\delta$, Peckham coll., (MCZ, Harvard).

REMARKS. The pustuliform fields could not be examined properly because of damage and 

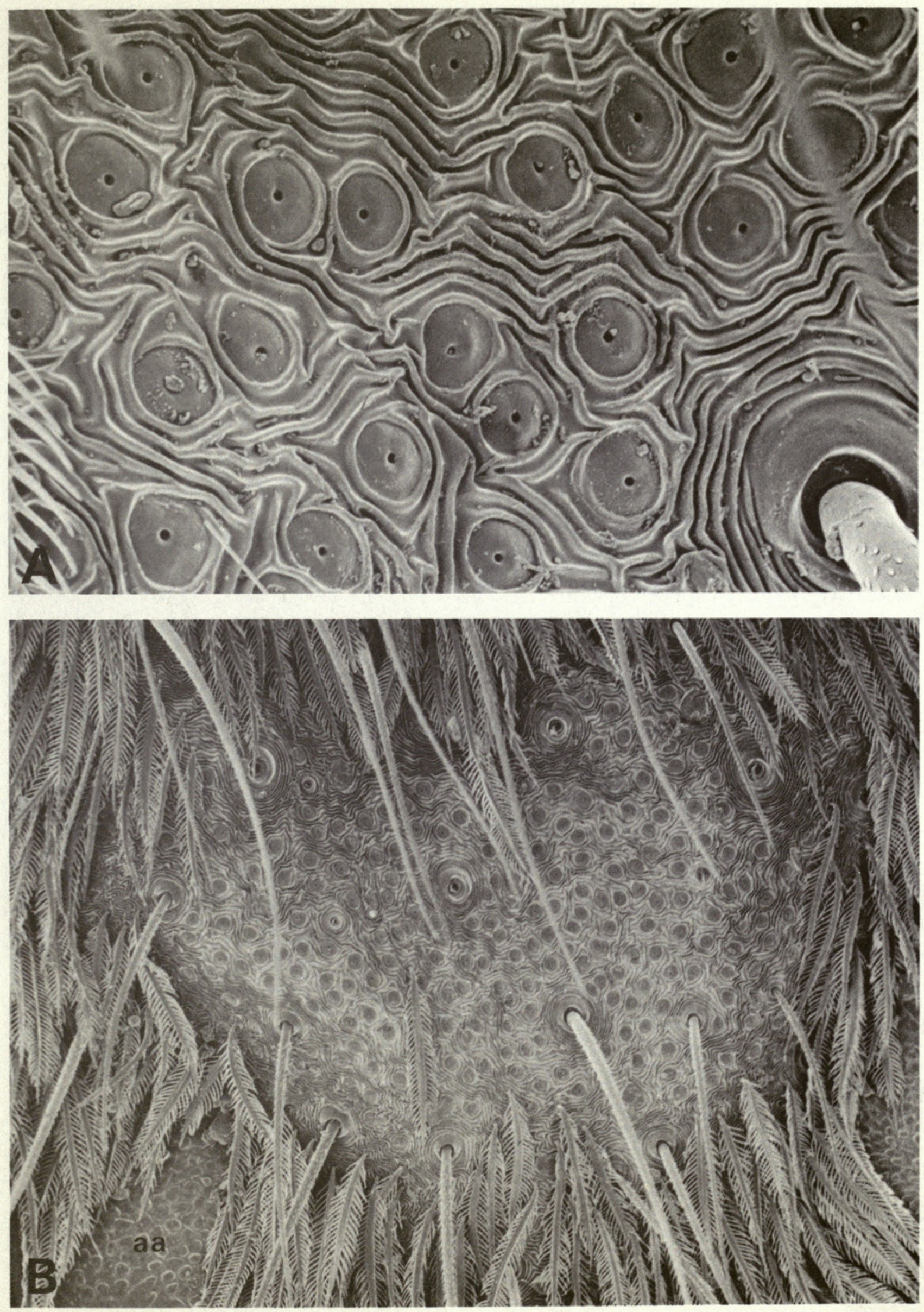

Fig. 12 Holcolaetis vellerea Simon,, : dorsal surface of abdomen showing pustuliform field: A, $\times 900$; $\mathrm{B}, \times 168$. 

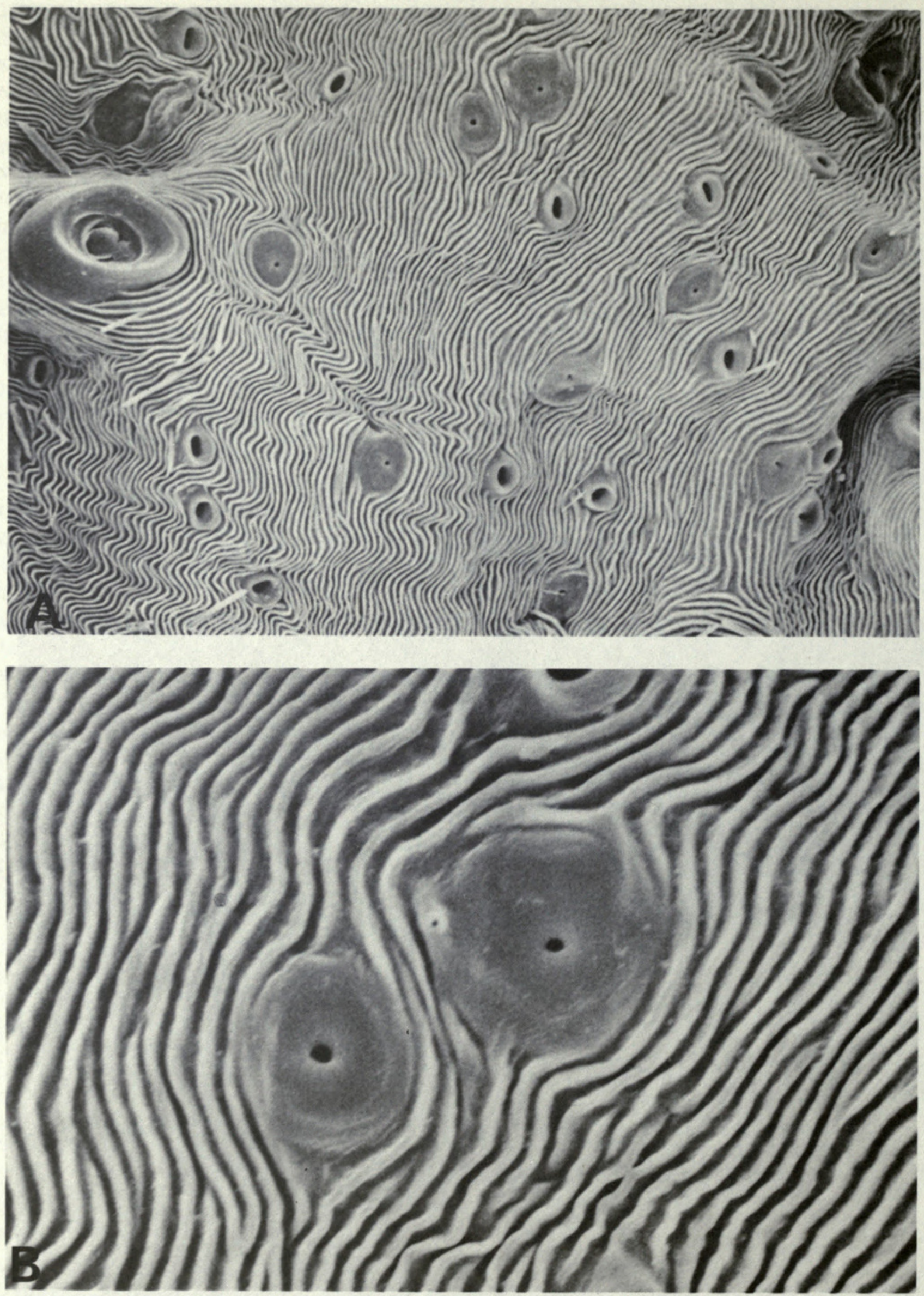

Fig. 13 Sonoita lightfooti Peckham \& Peckham, subadult + pustuliform organs: A, $\times 1300 ; \mathrm{B}, \times 4500$. 

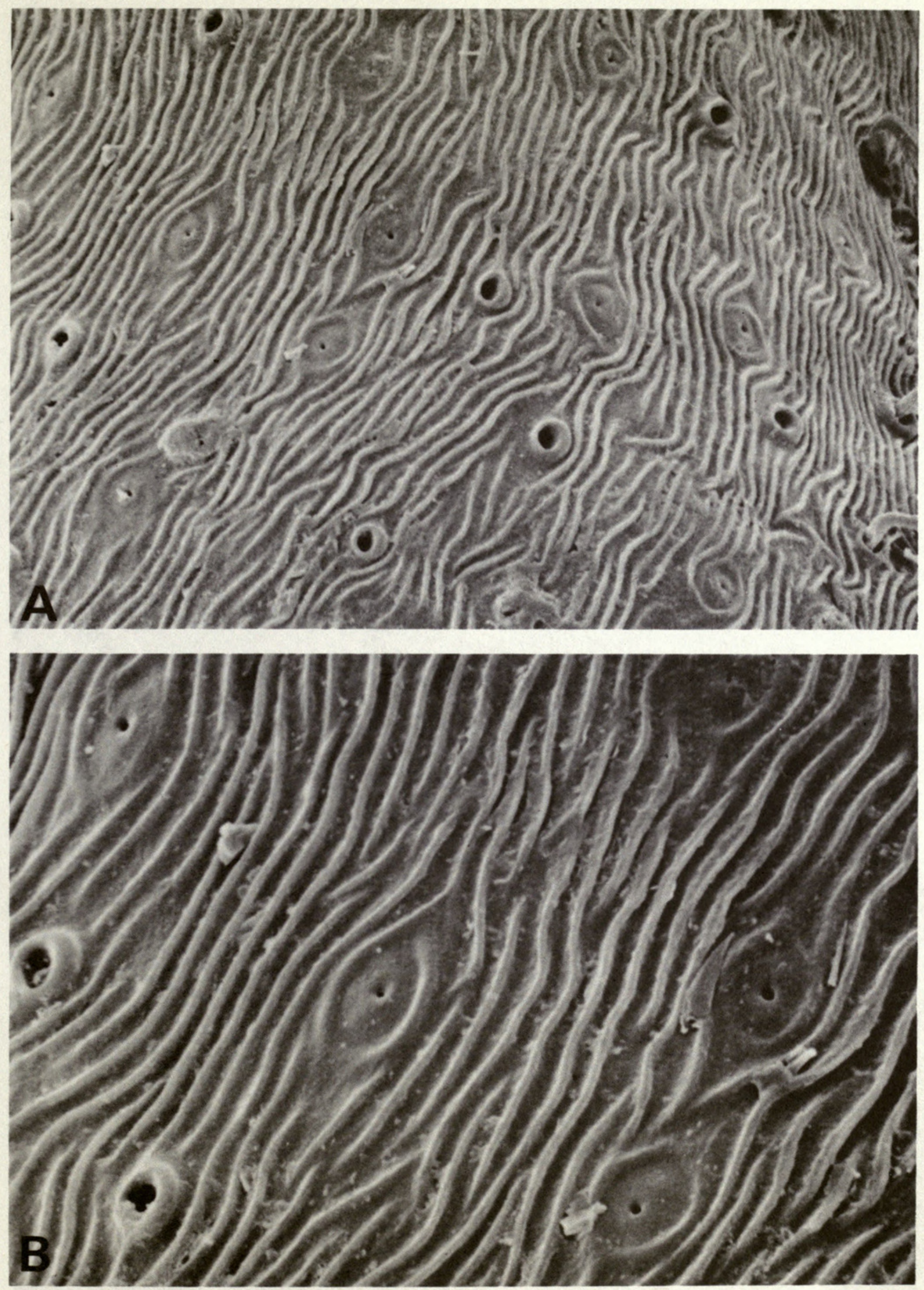

Fig. 14 Sonoita lightfooti Peckham \& Peckham, o pustuliform organs: A, $\times 1400 ; \mathrm{B}, \times 3000$. 

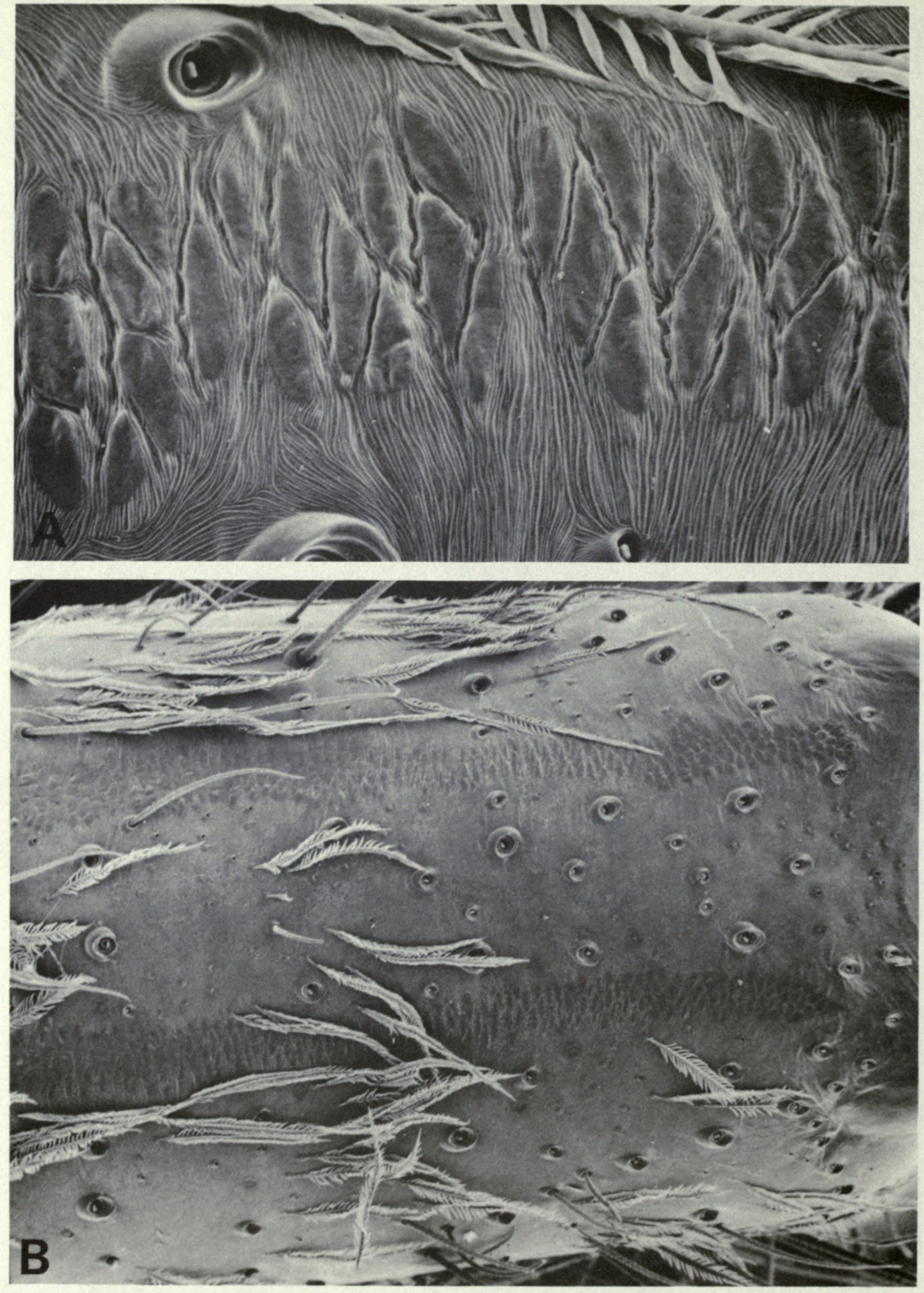

Fig. 15 Holcolaetis vellerea Simon, o: dorsal surface of tibia I showing hinge lines: A, $\times 1300$; B, $\times 168$. 

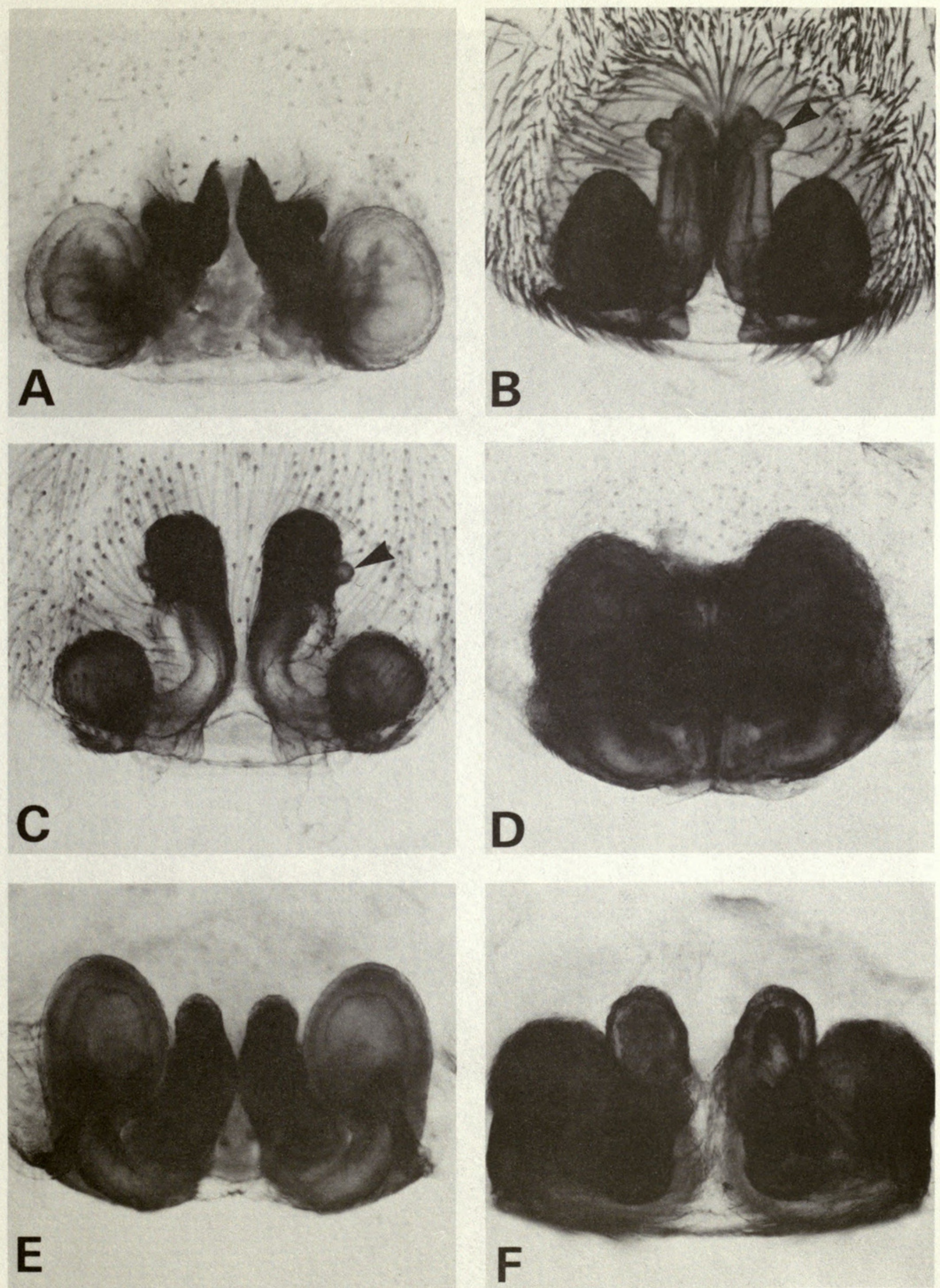

Fig. 16 A, Holcolaetis xerampelina Simon, vulva, outer view. B, H. vellerea Simon, vulva, outer view; C, H. zuluensis Lawrence, vulva, outer view. D, H. albobarbata Simon, vulva, outer view. E, H. clarki sp. n., vulva, inner view. F, Sonoita lightfooti Peckham \& Peckham, vulva, inner view. 

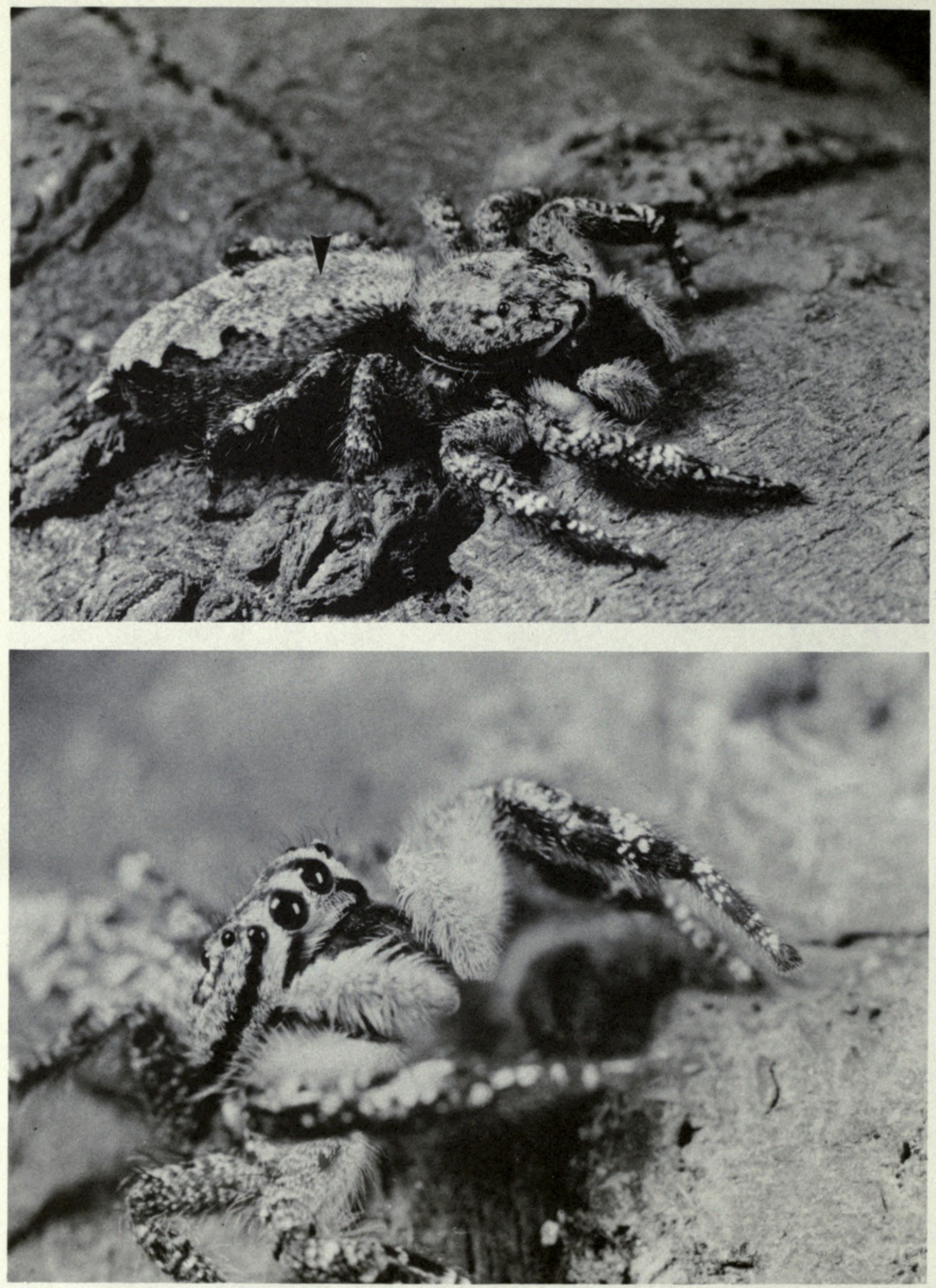

Fig. 17 Holcolaetis vellerea Simon, + from Kenya, notice semirecumbent tufts of white hairs on legs and position of pustuliform field indicated, by an arrow. 

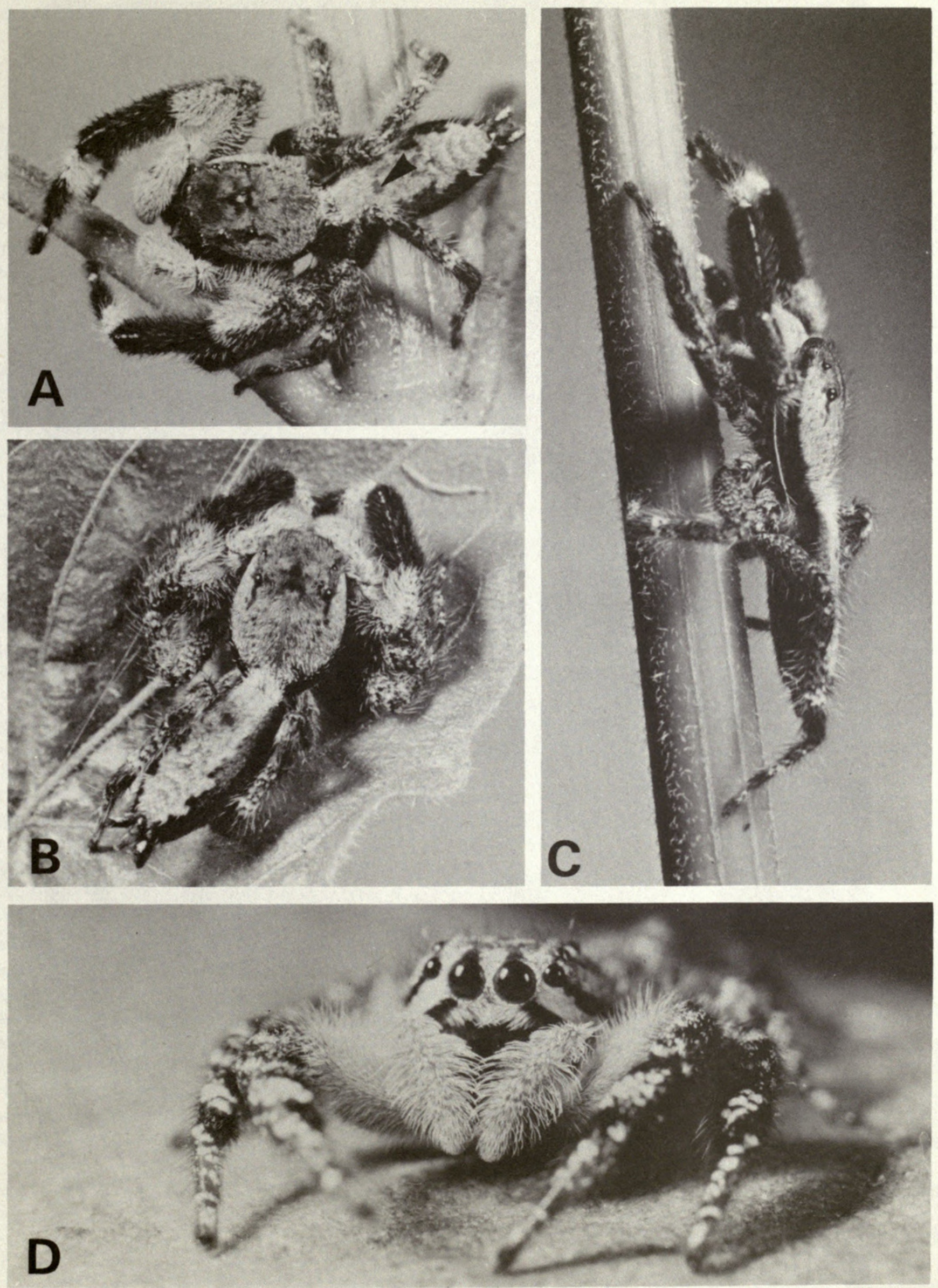

Fig. 18 Holcolaetis vellerea Simon, from Kenya: A-C, ô, pustuliform field indicated by an arrow; D,,. 

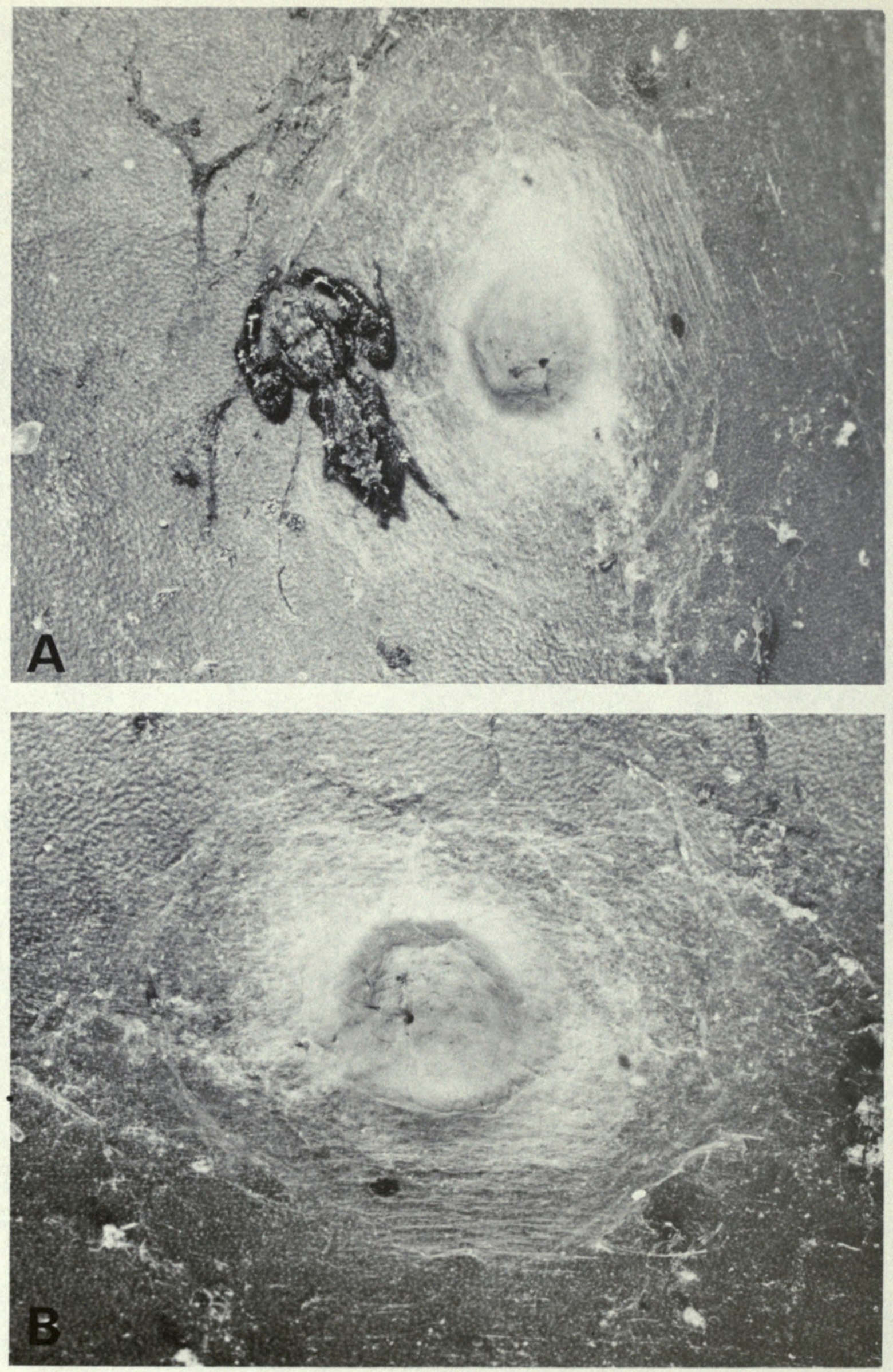

Fig. 19 Holcolaetis vellerea Simon, A, \& with gnaphosid-like egg-sac; B, egg-sac. 
shrinkage in the only available specimens. Provisional observations indicate that the fields are comprised of fewer and more scattered pustuliform organs (Figs 13,14) and when compared with those of Holcolaetis, they are possibly less well developed.

\section{Acknowledgements}

I am grateful to $\mathrm{Mr} \& \mathrm{Mrs} \mathrm{J}$. Murphy, London for allowing me to study their important collection of African Salticids. Mrs F. Murphy supplied the photographs for figures 17-18 and Dr R. R. Jackson the photographs for figure 19 .

Colleagues kindly made types and other material available for study: Dr R. Jocqué, Musée Royal d'Afrique Centrale, Tervuren, Belgium (MRAC, Tervuren); Dr M. Grasshoff, Forschungsinstitut Senckenberg, Natur-Museum, Senkenberg, Frankfurt am Main, W. Germany (FS, Frankfurt am Main); Dr C. Griswold, Natal Museum, Pietermaritzburg, South Africa (NM, Pietermaritzburg); M. M. Hubert, Muséum National d'Histoire Naturelle, Paris, France (MNHN, Paris); Dr R. R. Jackson, University of Canterbury, Christchurch, New Zealand; Professor T. Kronestedt, Naturhistoriska, Riksmuseet, Stockholm, Sweden (NR, Stockholm); Professor H. W. Levi, Museum of Comparative Zoology, Harvard, U.S.A. (MCZ, Harvard); Ms S. Mascherini, Museo Zoologico de la Specola, Firenze, Italy (MZS, Firenze);

Dr N. I. Platnick, American Museum of Natural History, New York, U.S.A. (AMNH, New York).

Finally I would like to thank Mr K. H. Hyatt (BMNH) for reading the manuscript.

\section{References}

Bonnet, P. 1957. Bibliographia Araneorum 2(3): 1927-3026. Imprimerie Douladoure, Toulouse. 1958. Bibliographia Araneorum 2(4): 3027-4230. Imprimerie Douladoure, Toulouse.

Brignoli, P. M. 1983. A catalogue of the Araneae described between 1940 and 1981. Manchester University Press in association with The British Arachnological Society.

Caporiacco, L. di 1940. Arachnidi raccolti nella regione dei Laghi Etiopici della Fossa Galla. Atti r. Accad. Ital. Memorie 11 (18): 767-837.

1941. Arachnida. Missione Biol. Sagan-Omo. 12 Zool. 6: 159 pp.

Clark, D. J. 1974. Notes on Simon's types of African Salticidae. Bull. Br. arachnol. Soc. 3 (1): 11-27.

Cutler, B. 1976. A catalogue of the jumping spiders of Southern Africa. (Araneae: Lyssomanidae and Salticidae). Cimbebasia (A) 4: 129-135.

Dyal, S. 1935. 4. Spiders of Lahore. Bull. Dep. Zool. Punjab Univ. 1: 119-252.

Humphreys, W. F. 1983. The surface of spiders' eggs. J. Zool. Lond. 200: 303-316. 1985. Spider pheromone 'packets'. Nature, Lond. $315: 104$.

Lessert, R. de 1925a. Araignées du Sud de l'Afrique. Revue suisse Zool. 31 (13): 429-528. 1925b. Araignées du Sud de l'Afrique. Revue suisse Zool. 32 (21): 323-365.

1927. Araignées du Congo. Part 1. Revue suisse Zool. 34 (17): 405-475.

Lawrence, R. F. 1937. A collection of Arachnida from Zululand. Ann. Natal Mus. 8 (2): 211-273.

Neave, S. A. 1939. Nomencl. Zool. II, D-L: 1025 pp. Zoological Society, London. 1940. Nomencl. Zool. IV, Q-Z, and supplement, $758 \mathrm{pp}$. Zoological Society, London.

Parry, D. A. 1957. Spider leg-muscles and the autonomy mechanism. Q. Jl microsc. Sci. 98: 331-340.

Peckham, G. W. \& Peckham, E. G. 1903. New species of the family Attidae from South Africa, with notes on the distribution of the genera found in the Ethiopian Region. Trans. Wis. Acad. Sci. Arts Lett. 14: 173-278.

Petrunkevitch, A. 1928. Systema Aranearum. Trans. Conn. Acad. Arts Sci. 29: 270 pp.

Prószyński, J. 1971. Catalogue of Salticidae (Aranei) specimens kept in major collections of the world. Annls zool. Warsz. 28 (17): 367-519.

Roewer, C. Fr. 1954. Katalogue der Araneae. 2, Abt. B: 924-1290. Institute Royal des Sciences Naturelle de Belgique, Bruxelles.

- 1965. Die Lyssomanidae und Salticidae-Pluridentati der Äthiopischen Region (Araneae). Annls Mus. r. Afr. cent. 139: $86 \mathrm{pp}$.

Simon, E. 1886. Études Arachnologiques 18e Memoire (1) XXVI Matériaux pour servir à la faune des arachnides du Sénégal. Annls Soc. ent Fr. (6) 5: 345-396.

1901. Histoire Naturelle des Araignées 2 (3): 381-668. Roret: Libraire Encyclopédique, Paris.

1909 (1910). Arachnides recueillis par L. Fea sur la Côte Occidentale d'Afrique 2.e partie. Mus. civ.

Stor. nat. Giacomo Doria 3 (3): [ =44]: 335-449. 
Strand, E. 1909. Nordafrikanische, hauptsächlich von Carlo Freiherr von Erlanger gesammelte Oxyopiden und Salticiden (Forts u. Schluss.). Societas ent. 23: 180-181.

Wanless, F. R. 1978. A revision of the spider genera Belippo and Myrmarachne (Araneae: Salticidae) in the Ethiopian Region. Bull. Br. Mus. nat. Hist. (Zool.) 33: 139 pp.

1982. A revision of the spider genus Cocalodes with a description of a new related genus (Araneae: Salticidae). Bull. Br. Mus. nat. Hist. (Zool.) 42: 263-298.

$-1984 a$. A revision of the spider subfamily Spartaeinae nom. n. (Araneae: Salticidae) with descriptions of six new genera. Bull. Br. Mus. nat. Hist. (Zool.) 46: 135-205.

1984b. A revision of the spider genus Cyrba (Araneae: Salticidae) with the description of a new presumptive pheromone dispersing organ. Bull. Br. Mus. nat. Hist. (Zool.) 47: 445-481.

Waterhouse, C. O. 1902. Index zoologicus No I, 421 pp. 1912. Index zoololgicus No II, 324 pp. 


\section{$2 \mathrm{BHL}$ Biodiversity Heritage Library}

Wanless, F. R. 1985. "A revision of the spider genera Holcolaetis and Sonoita (Araneae: Salticidae)." Bulletin of the British Museum (Natural History) Zoology 48, 249-278. https://doi.org/10.5962/bhl.part.23463.

View This Item Online: https://www.biodiversitylibrary.org/item/19651

DOI: https://doi.org/10.5962/bhl.part.23463

Permalink: https://www.biodiversitylibrary.org/partpdf/23463

\section{Holding Institution}

Natural History Museum Library, London

\section{Sponsored by}

Natural History Museum Library, London

\section{Copyright \& Reuse}

Copyright Status: In copyright. Digitized with the permission of the rights holder.

Rights Holder: The Trustees of the Natural History Museum, London

License: http://creativecommons.org/licenses/by-nc-sa/4.0/

Rights: http://biodiversitylibrary.org/permissions

This document was created from content at the Biodiversity Heritage Library, the world's largest open access digital library for biodiversity literature and archives. Visit BHL at https://www.biodiversitylibrary.org. 